\title{
Glimepiride reduces CD14 expression and cytokine secretion from macrophages
}

\author{
Victoria Ingham', Alun Williams ${ }^{2}$ and Clive Bate ${ }^{1 *}$
}

\begin{abstract}
Background: Activated microglia are associated with deposits of aggregated proteins within the brains of patients with Alzheimer's disease (AD), Parkinson's disease (PD) and prion diseases. Since the cytokines secreted from activated microglia are thought to contribute to the pathogenesis of these neurodegenerative diseases, compounds that suppress cytokine production have been identified as potential therapeutic targets. CD14 is a glycosylphosphatidylinositol (GPI)- anchored protein that is part of a receptor complex that mediates microglial responses to peptides that accumulate in prion disease (PrP82-146), AD (amyloid- $\beta(A \beta)_{42}$ ) and PD (a-synuclein $(a \mathrm{SN})$ ). As some GPI-anchored proteins are released from cells by treatment with glimepiride, a sulphonylurea used for the treatment of diabetes, the effects of glimepiride upon CD14 expression and cytokine production from cultured macrophages were studied.
\end{abstract}

Methods: RAW 264 cells and microglial cells were treated with glimepiride or phosphatidylinositol (PI)-phospholipase C (PLC) and the expression of cell receptors was analysed by ELISA and immunoblot. Treated cells were subsequently incubated with $A \beta_{42}$, aSN, PrP82-146 or lipopolysaccharide (LPS) and the amounts of Toll-like receptor (TLR)-4, tumour necrosis factor (TNF), interleukin (IL)-1 and IL-6 measured.

Results: Glimepiride released CD14 from RAW 264 cells and microglial cells. Pre-treatment with glimepiride significantly reduced TNF, IL-1 and IL-6 secretion from RAW 264 and microglial cells incubated with LPS, A $\beta_{42}$, aSN and PrP82-146. Glimepiride also reduced the LPS, A $\beta_{42}$, aSN and PrP82-146-induced translocation of TLR-4 into membrane rafts that is associated with cell activation. These effects of glimepiride were also seen after digestion of RAW 264 cells with PI-phospholipase C (PLC). In addition, the effects of glimepiride were blocked by pharmacological inhibition of GPI-PLC. The cytokine production was CD14-dependent; it was reduced in microglia from CD14 knockout mice and was blocked by antiserum to CD14.

Conclusions: RAW 264 and microglial cell responses to $A \beta_{1-42}$, aSN, PrP82-146 and LPS are dependent upon CD14 expression. Glimepiride induced the shedding of CD14 from cells by activation of GPI-PLC and consequently reduced cytokine production in response to A $\beta_{42}$ aSN, PrP82-146 and LPS. These results suggest that glimepiride acts as a novel anti-inflammatory agent that could modify the progression of neurodegenerative diseases.

\section{Background}

The deposition of aggregated proteins within the brain is a common feature of neurodegenerative diseases including Alzheimer's disease (AD), Parkinson's disease (PD) and prion diseases. These aggregates are often surrounded by activated microglial cells, the resident macrophage-like cells of the brain [1-3] and, in vitro aggregated forms of disease-associated peptides stimulate cytokine secretion

\footnotetext{
* Correspondence: cbate@rvc.ac.uk

'Department of Pathology and Pathogen Biology, Royal Veterinary College, Hawkshead Lane, North Mymms, Herts, London, UK

Full list of author information is available at the end of the article
}

from microglia/macrophages [3-6]. Numerous studies suggest that cytokine-induced neuroinflammation contributes to the clinical progression of $\mathrm{AD}, \mathrm{PD}$ and prion diseases [7-9]. For example, epidemiological studies reported that the use of non-steroidal anti-inflammatory drugs delayed the progression of dementia, PD and AD [10-12] and the beneficial effects of statin therapy on dementia [13] have been attributed to their anti-inflammatory properties [14]. While it is difficult to ascertain the extent of cytokine secretion that occurs within the brain directly, the addition of fibrillar forms of amyloid- $\beta$ (A $\left.\beta_{1-42}\right)$, $\alpha$-synuclein $(\alpha \mathrm{SN})$ or the prion-derived peptide (PrP82- 
146) stimulated the secretion of cytokines from cultured macrophages and microglia [3,15-17]. In this study the responses of a macrophage cell line (RAW 264 cells) and primary microglial cells that secrete tumour necrosis factor (TNF) and interleukins (IL) 1 and IL-6 [18] in response to PrP82-146, $\mathrm{A} \beta_{1-42}$ and $\alpha \mathrm{SN}$ were studied.

It has been suggested that drugs that reduce cytokine secretion from macrophages might be of therapeutic benefit in AD and PD [19]. While multiple receptors have been reported to be involved in macrophage responses to aggregated neurotoxic proteins [20], including scavenger receptors [21] and CD40 [22], other studies implicate CD14, a protein that is highly expressed on myeloid cells including microglia [23], as a key component of the receptor complex that mediates cytokine secretion induced by fibrillar A $\beta$ peptides [16], prion-damaged neurons [24] and lipopolysaccharide (LPS) [25,26]. Furthermore, the genetic deletion of CD14 attenuates pathology in a murine model of AD [27]. We therefore hypothesised that any compound that reduces the expression of CD14 on microglia/macrophages may also reduce cytokine secretion and consequently ameliorate the rate of cognitive decline. Little is known about what factors control the expression of CD14 on macrophages. However, CD14 is linked to the membrane via a glycosylphosphatidylinositol (GPI) anchor [28] and like other GPI-anchored proteins is found in soluble forms. Thus, soluble CD14 found in the bloodstream can reduce cytokine secretion from macrophages [29] and prevent mortality in LPS-treated mice [30]. More recently, the concentrations of soluble CD14 were found to be elevated in $A D$ and $P D$ patients and were associated with glial cell suppression [31]. Collectively such observations suggest that either a reduction of cell-associated CD14, or an increase in soluble CD14 in extracellular fluids, can reduce cytokine secretion from macrophages.

Glimepiride, a sulphonylurea used to treat diabetes [32], is able to mimic insulin signalling and activate an endogenous GPI-phospholipase C (PLC) [33] resulting in the release of some GPI-anchored proteins from the surface of adipocytes [34] and neurons [35]. For this reason, its effects upon macrophages were examined in this study. We report that glimepiride-treated RAW 264 and microglial cells expressed lower amounts of CD14 and produced fewer cytokines when incubated with PrP82-146, A $\beta_{1-42}$, $\alpha \mathrm{SN}$ or LPS than control cells.

\section{Methods}

\section{Cell lines}

The murine RAW 264 cell line was grown in Ham's F12 medium supplemented with $2 \mathrm{mM}$ glutamine, 5\% foetal calf serum (FCS) (PAA, www.gelifesciences.com/PAA) and standard antibiotics $(100 \mathrm{U} / \mathrm{ml}$ penicillin and $100 \mu \mathrm{g} / \mathrm{ml}$ streptomycin - Invitrogen, www.lifetechnologies.com/uk). Cells were seeded in 48-well plates at $2 \times 10^{5}$ cells per well and allowed to adhere overnight. Cells were pre-treated with test compounds including glimepiride, glipizide, p-chloromercuriphenylsulphonate (p-CMPS), polymyxin $\mathrm{B}$ or phosphatidylinositol (PI)-PLC derived from Bacillus cereus, (all obtained from Sigma) or with antibodies to CD14 (goat polyclonal IgG anti-mouse CD14 (R\&D Systems, www.rndsystems.com), $\operatorname{PrP}^{\mathrm{C}}$ (mouse mAb 4 F2) or CD55 (rat mAb 3D5 Abcam) for one hour before the addition of LPS (Sigma, www.sigmaaldrich.com), PrP82$146, \alpha \mathrm{SN}$ or $\mathrm{A} \beta_{42}$. Cell supernatants were collected 24 hours later and tested for cytokines or CD14. Cell extracts were also collected and tested for CD14 and Toll-like receptor (TLR)-4. Experiments were performed in triplicate wells. Levels of TNF, IL-1 and IL- 6 were assayed by sandwich enzyme-linked immunoassays (ELISA)s using matched pairs of antibodies (see below).

\section{Microglial cells}

These were prepared by dissociating cerebral cortices of newborn mouse pups derived from C57Bl/B6J, CD14 wild type and from C57Bl/B6J, CD14 knockout mice (Jackson Laboratory, www.jax.org) as described [36]. Cell suspensions were prepared by repeated passage through a fine bore pipette and debris was removed by filtration through a $100 \mu \mathrm{M}$ cell strainer. Cells were suspended in Ham's F12 medium containing $2 \mathrm{mM}$ glutamine, standard antibiotics and $10 \%$ FCS, and placed into polyL-lysine coated $75 \mathrm{~cm}^{3}$ flasks. Cultures were maintained at $37^{\circ} \mathrm{C}$ with $5 \% \mathrm{CO}_{2}$ for two weeks or until glial cultures were confluent. Microglial cells were isolated by shaking cultures at $260 \mathrm{rpm}$ for 2 hours. Detached cells were collected, counted and dispensed at $2 \times 10^{5}$ cells per well in 48 -well plates. Greater than $90 \%$ of cells stained positive for the mouse macrophage marker protein F4/80 (Serotec, www.abdserotec.com/).

\section{Cell extracts}

At the end of treatments, cells were washed twice in PBS and homogenised in an extraction buffer containing 10 $\mathrm{mM}$ Tris- $\mathrm{HCl}$ at $\mathrm{pH}$ 7.4, $100 \mathrm{mM} \mathrm{NaCl}, 10 \mathrm{mM}$ ethylenediaminetetraacetic acid (EDTA), 0.5\% Nonidet P-40, 0.5\% sodium deoxycholate, $0.2 \%$ sodium dodecyl sulphate (SDS) and mixed protease inhibitors (4-(2-aminoethyl) benzenesulfonyl fluoride, aprotinin, leupeptin, bestatin, pepstatin A and E-46 - Sigma) at $10^{6}$ cells $/ \mathrm{ml}$. Membranes were prepared by repeated passage with a Wheaton homogeniser; nuclei and large fragments were removed by centrifugation (300 $\times g$ for 5 minutes).

Isolation of detergent resistant membranes (DRMs)/lipid rafts Cells were lysed in an ice-cold buffer containing 1\% Triton $\mathrm{X}-100,10 \mathrm{mM}$ Tris- $\mathrm{HCl}$ (pH 7.2), $100 \mathrm{mM} \mathrm{NaCl}, 10 \mathrm{mM}$ EDTA and mixed protease inhibitors $\left(10^{6}\right.$ cells $\left./ \mathrm{ml}\right)$. Membranes were prepared by homogenisation and nuclei and 
large fragments were removed by centrifugation $(300 \times g$ for 5 minutes). The post nuclear supernatant was incubated on ice for 60 minutes prior to further centrifugation $\left(16,000 \times g\right.$ for 30 minutes at $\left.4^{\circ} \mathrm{C}\right)$. The soluble material was reserved as the normal cell membrane. The pellets were solubilised in extraction buffer $(10 \mathrm{mM}$ Tris- $\mathrm{HCl}$, $10 \mathrm{mM} \mathrm{NaCl}, 10 \mathrm{mM}$ EDTA, 0.5\% Nonidet P-40, 0.5\% sodium deoxycholate and $0.2 \%$ SDS and mixed protease inhibitors, centrifuged again $(10$ minutes at $16,000 \times g$ ) and the supernatant reserved as the lipid raft fraction.

\section{IL-1 $\beta$ ELISA}

A monoclonal antibody to IL- $1 \beta$ ( $R \& D$ systems) was diluted to $2 \mu \mathrm{g} / \mathrm{ml}$ in carbonate buffer and dispensed in 96-well Maxisorb Immunoplates (Nunc, Roskilde, Denmark) overnight. Samples were added for one hour, followed by the secondary antibody (a biotinylated goat anti-mouse IL-1 $\beta$ (R\&D systems)). Extravidin-alkaline phosphatase (1:1,000, Sigma) was added for 1 hour after which $1 \mathrm{mg} / \mathrm{ml}$ 4-nitrophenyl phosphate substrate (Sigma) was added. After 20 minutes, plates were read at $450 \mathrm{nM}$ and results were calculated by reference to a standard curve of recombinant murine IL-1 $\beta$ (R\&D systems).

\section{IL-6 ELISA}

A monoclonal antibody to IL-6 was diluted to $2 \mu \mathrm{g} / \mathrm{ml}$ in carbonate buffer and dispensed in 96-well Maxisorb Immunoplates overnight. Samples were added for one hour, followed by the secondary antibody (a polyclonal anti-mouse IL-6 conjugated to alkaline phosphatase (R\&D systems)) which was detected using $1 \mathrm{mg} / \mathrm{ml}$ 4-nitrophenyl phosphate. Plates were read at $450 \mathrm{nM}$ and results were calculated by reference to a standard curve of recombinant murine IL-6 (R\&D systems).

\section{TNF ELISA}

Polyclonal IgG to TNF (R\&D systems) was diluted to 2 $\mu \mathrm{g} / \mathrm{ml}$ in carbonate buffer and dispensed in 96-well Maxisorb Immunoplates overnight. Samples were added for one hour, followed by the detection antibody, a biotinylated anti-mouse TNF polyclonal antibody (R\&D systems) added at $200 \mathrm{ng} / \mathrm{ml}$. A 1:5,000 dilution of extravidinalkaline phosphatase was then added for a further hour followed by the addition of $1 \mathrm{mg} / \mathrm{ml}$ 4-nitrophenyl phosphate. Plates were read at $450 \mathrm{nM}$ and results were calculated by reference to a standard curve of recombinant murine TNF (R\&D systems).

\section{CD14 ELISA}

Maxisorb Immunoplates were coated with $0.5 \mu \mathrm{g} / \mathrm{ml}$ rat IgG1 anti-mouse CD14 mAb (clone RmC5-3) (BD Biosciences, www.bdbiosciences.com). Samples were applied and the amount of bound CD14 was measured using a goat polyclonal IgG anti-mouse CD14 (R\&D Systems), followed by anti-goat IgG conjugated to alkaline phosphatase (Sigma) and $1 \mathrm{mg} / \mathrm{ml}$ 4-nitrophenyl phosphate (Sigma). Absorbance was measured on a microplate reader at $405 \mathrm{~nm}$. Results were reported as units CD14 where 100 units = amount of CD14 in $10^{6}$ control RAW 264 cells.

\section{TLR-4 ELISA}

Maxisorb Immunoplates were coated with $0.5 \mu \mathrm{g} / \mathrm{ml}$ of mouse monoclonal to TLR-4 (Abcam - ab22048) (epitope 100 to 200) and blocked with 5\% milk powder. Samples were applied (one hour at room temperature) and the amounts of TLR-4 were measured using a rabbit polyclonal IgG to TLR-4 (Abcam - ab13556) (epitope 420 to 435), followed by anti-rabbit IgG conjugated to alkaline phosphatase and $1 \mathrm{mg} / \mathrm{ml}$ 4-nitrophenyl phosphate. Absorbance was measured on a microplate reader at $405 \mathrm{~nm}$. Results were reported as\% TLR-4 where $100 \%=$ amount of TLR-4 in cell extracts from control RAW 264 cells.

\section{PrP82-146 ELISA}

The amount of PrP82-146 in cell extracts was determined by ELISA as described [35]. Maxisorb Immunoplates were coated with mAb 3 F4 (Abcam, www.abcam. com). Samples were boiled with $0.2 \%$ SDS to denature peptide and incubated for one hour. Bound PrP82-146 was detected with biotinylated ICSM35 (a gift from Dr Mourad Tayebi), followed by extravidin-alkaline phosphatase and $1 \mathrm{mg} / \mathrm{ml}$ 4-nitrophenyl phosphate. Absorbance was measured on a microplate reader at $405 \mathrm{~nm}$ and the amount of PrP82-146 in cell extracts was calculated by reference to a standard curve of PrP82-146.

\section{$A \beta_{42}$ ELISA}

Maxisorb Immunoplates were coated with mAb 4G8 (epitope 17 to 24) (Covance, www.bioscience.co.uk/covance) in carbonate buffer overnight. Plates were blocked with $5 \%$ milk powder in PBS-Tween and samples were applied. The detection antibody was an $A \beta_{42}$ selective rabbit $\mathrm{mAb}$ BA3-9 (Covance) followed by biotinylated anti-rabbit IgG (Sigma). Total A $\beta$ was visualised by addition of $1 \mathrm{mg} / \mathrm{ml}$ 4-nitrophenyl phosphate and optical density was read in a spectrophotometer at $405 \mathrm{~nm}$. Absorbance was measured on a microplate reader at $405 \mathrm{~nm}$ and results were calculated by comparison to serial dilutions of synthetic $A \beta_{1-42}$.

\section{Western blot analysis}

Samples were mixed with Laemmli buffer, heated to $95^{\circ} \mathrm{C}$ and subjected to electrophoresis on $15 \%$ polyacrylamide gels. Proteins were transferred onto a Hybond-P PVDF membrane (Amersham Biotech, www.gelifesciences.com) by semi-dry blotting. Membranes were blocked with $10 \%$ milk powder and incubated with either mAb ICSM35 (to detect $\operatorname{PrP}^{\mathrm{C}}$ ), goat polyclonal IgG anti-mouse CD14 (R\&D Systems), sheep polyclonal anti-CD55 (R\&D Systems) or 
with rabbit polyclonal antibodies to caveolin (Upstate, www. millipore.com), followed by a secondary anti-mouse, rabbit or goat IgG conjugated to peroxidase (Sigma). Bound antibody was visualised using enhanced chemiluminescence.

\section{Peptides}

Synthetic peptides containing amino acids 82 to 146 of the human PrP protein (PrP82-146) corresponding to a $\operatorname{PrP}$ fragment found in prion-infected brains, and a control peptide (PrP82-146scrambled) were supplied by Professor Mario Salmona (Mario Negri Institute, Milan). A synthetic peptide containing the amino acid residues 1 to 42 of the $A \beta$ protein $\left(A \beta_{1-42}\right)$ and a control peptide consisting of the same amino acids in reverse order $\left(A \beta_{42-1}\right)$ were obtained from Bachem. Stock solutions of peptides were stored at $1 \mathrm{mM}$ in dimethyl sulphoxide and thawed on the day of use before dilution in culture medium, sonication and addition to cells. Recombinant $\alpha \mathrm{SN}$ and $\beta \mathrm{SN}$ were purchased from Sigma.

\section{Statistical methods}

Differences between treatment groups were assessed using Student's, two sample, paired- $t$ tests. In all tests statistical significance was set at the $5 \%$ level.

\section{Results}

\section{Glimepiride stimulated the release of CD14 from RAW}

\section{4 cells}

Since glimepiride stimulated the release of some GPIanchored proteins from adipocytes [34] and neurons [35] the effect of glimepiride on the expression of GPIanchored proteins in RAW 264 cells was examined. The amount of CD14 in RAW 264 cells treated with glimepiride for one hour was reduced in a dose-dependent manner (Figure 1A); the loss of CD14 from RAW 264 cells was accompanied by a corresponding increase in the amount of CD14 in the supernatant of these cells (Figure 1B). These effects occurred at non-toxic concentrations of glimepiride, thus the addition of $5 \mu \mathrm{M}$ glimepiride did not significantly alter cell survival as measured by thiazolyl blue tetrazolium ( $97 \%$ cell viability \pm 6 compared with $100 \% \pm 7, \mathrm{n}=12, P=0.24$ ). Pre-treatment of RAW 264 cells with $5 \mu \mathrm{M}$ glipizide, another sulphonylurea used to treat diabetes, did not affect the amounts of CD14 in cells (data not shown). The effects of glimepiride were not CD14 specific; it also reduced the amount of the GPI-anchored cellular prion protein $\left(\mathrm{PrP}^{\mathrm{C}}\right)$ in cells, but did not affect the amounts of GPI-anchored CD55 or caveolin (Figure 1C). Glimepiride, but not glipizide, had a similar effect upon microglial cells; treatment with $5 \mu \mathrm{M}$ glimepiride reduced cellular CD14 and increased the amounts of soluble CD14 in the supernatant (Figure 1D). Glimepiride caused a dose-dependent increase in the amounts of soluble CD14 as measured by Western blot (Figure 1E).

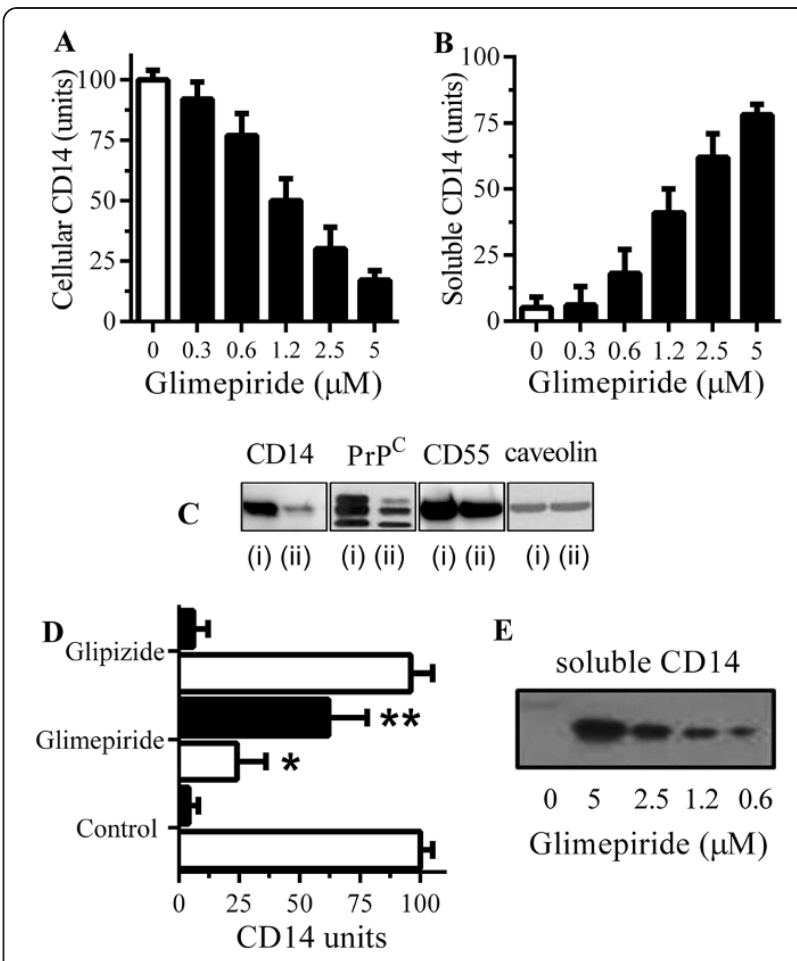

Figure 1 Glimepiride releases CD14 from RAW 264 cells. (A) The amounts of CD14 in RAW 264 cells treated for one hour with control medium ( $\square$ ) or glimepiride ( $\square$ ) as shown. Values are means \pm SD, from triplicate experiments performed 4 times, $n=12$. (B) The amounts of CD14 in supernatants from RAW 264 cells treated for one hour with control medium ( $\square$ ) or glimepiride as shown ( $\mathbf{\square})$. Values are means $\pm S D$, from triplicate experiments performed 4 times, $n=12$. (C) Immunoblots showing the amounts of CD14, PrPC, CD55 and caveolin in extracts from RAW 264 cells treated for 1 hour with control medium (i) or $5 \mu \mathrm{M}$ glimepiride (ii). (D) The amounts of CD14 in cells ( $\square$ ) or supernatants ( $\mathbf{a})$ from microglial cells treated for 1 hour with control medium, $5 \mu \mathrm{M}$ glimepiride or $5 \mu \mathrm{M}$ glipizide. Values are mean units CD14 \pm SD, from triplicate experiments performed 3 times, $n=9$. *Cellular CD14 significantly less than control cells. ${ }^{*}$ supernatant CD14 significantly greater than control supernatants. (E) Blot showing the amounts of CD14 in supernatants from microglial cells treated with concentrations of glimepiride as shown for one hour.

Glimepiride reduced cytokine secretion from RAW 264 cells The activation of microglial cells by aggregated peptides is thought to affect the progression of prion diseases. The addition of PrP82-146 increased the secretion of TNF from RAW 264 cells (Figure 2A). TNF production from cells incubated with a control peptide (PrP82146scrambled) was not significantly different from cells treated with control medium. The inclusion of $1 \mu \mathrm{g} / \mathrm{ml}$ polymyxin B, an antibiotic that blocks the effects of LPS, did not affect PrP82-146-induced TNF production, indicating that cytokine production was not due to contamination with this common bacterial contaminant. The effects of glimepiride on TNF secretion were then tested. The addition of $5 \mu \mathrm{M}$ glimepiride or $5 \mu \mathrm{M}$ glipizide did 

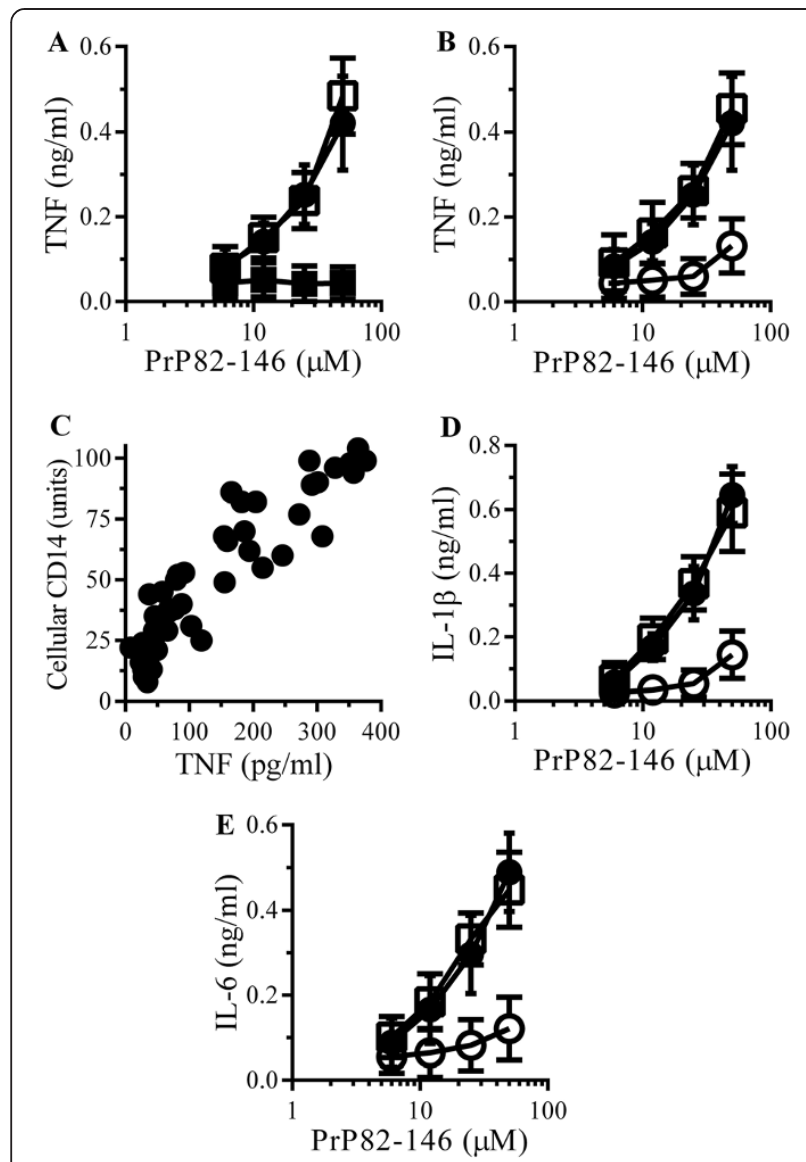

Figure 2 Glimepiride reduces cytokine secretion from RAW 264 cells incubated with PrP82-146. (A) The concentrations of TNF produced by RAW 264 cells incubated with PrP82-146 (•), PrP82-

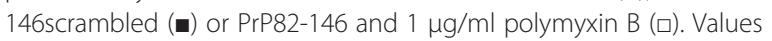
are means \pm SD from triplicate experiments performed 4 times, $n=12$ (B) The concentrations of TNF produced by RAW 264 cells pre-treated with control medium (•), $5 \mu \mathrm{M}$ glimepiride (o) or $5 \mu \mathrm{M}$ glipizide ( $\square$ ) and incubated with PrP82-146. Values are means \pm SD from triplicate experiments performed 4 times, $n=12$. (C) There was a significant correlation between the amounts of cellular CD14 of RAW 264 cells treated with glimepiride $(0.3$ to $5 \mu \mathrm{M})$ for 1 hour and TNF production after the addition of $50 \mu \mathrm{M}$ PrP82-146, Pearson's coefficient $=0.858$, $P<0.01$. (D) The concentrations of IL-1 $\beta$ produced by RAW 264 cells pre-treated with control medium (•), $5 \mu \mathrm{M}$ glimepiride (o) or $5 \mu \mathrm{M}$ glipizide ( $\square$ ) and incubated with PrP82-146. Values are means \pm SD from triplicate experiments performed 4 times, $n=12$. (E) The concentrations of IL- 6 produced by RAW 264 cells pre-treated with

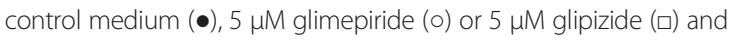
incubated with PrP82-146. Values are means \pm SD from triplicate experiments performed 4 times, $\mathrm{n}=12$.

not increase TNF production over that of control cells. However, pre-treatment with $5 \mu \mathrm{M}$ glimepiride, but not $5 \mu \mathrm{M}$ glipizide, significantly reduced the secretion of TNF from RAW 264 cells incubated with PrP82-146 (Figure 2B). The effects of glimepiride upon TNF production were dose-dependent; a significant correlation was observed between the amounts of cellular CD14 and TNF production following the addition of $50 \mu \mathrm{M}$ PrP82-146 (Figure 2C). Similarly, pre-treatment of RAW 264 cells with $5 \mu \mathrm{M}$ glimepiride, but not glipizide, significantly reduced the secretion of IL-1 $\beta$ (Figure $2 D$ ) or IL-6 (Figure 2E).

The addition of $A \beta_{1-42}$, but not $A \beta_{42-1}$, also caused the secretion of TNF from RAW 264 cells (Figure 3A). The $A \beta_{1-42}$-induced secretion of TNF was not affected by the inclusion of $1 \mu \mathrm{g} / \mathrm{ml}$ polymyxin B. Pre-treatment with $5 \mu \mathrm{M}$ glimepiride, but not $5 \mu \mathrm{M}$ glipizide, significantly reduced the $A \beta_{1-42}$-induced secretion of TNF (Figure 3B), IL-1 $\beta$ (Figure 3C) or IL-6 (Figure 3D). Similarly, the addition of $\alpha \mathrm{SN}$, but not $\beta S N$, caused the secretion of TNF from RAW 264 cells (Figure 4A). The $\alpha \mathrm{SN}$-induced secretion of TNF was not affected by the inclusion of $1 \mu \mathrm{g} / \mathrm{ml}$ polymyxin B. Pre-treatment with $5 \mu \mathrm{M}$ glimepiride, but not $5 \mu \mathrm{M}$ glipizide, significantly reduced the $\alpha \mathrm{SN}$-induced secretion of TNF (Figure 4B), IL-1 $\beta$ (Figure 4C) or IL-6 (Figure 4D) from RAW 264 cells.
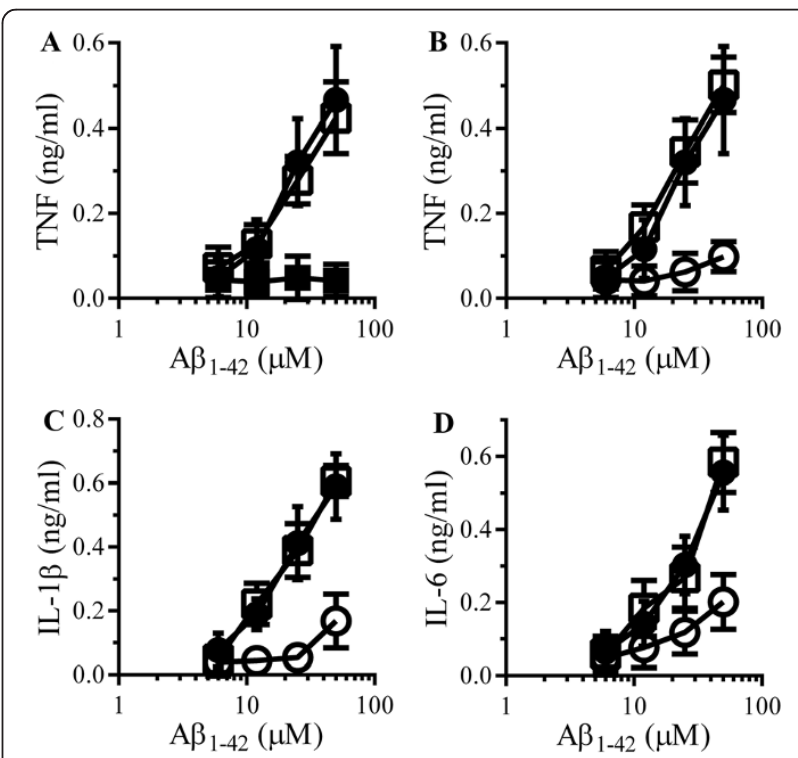

Figure 3 Glimepiride reduces cytokine secretion from RAW 264 cells incubated with $\mathbf{A} \boldsymbol{\beta}$. (A) The concentrations of TNF produced by RAW 264 cells incubated with $A \beta_{1-42}(\bullet), A \beta_{42-1}(\mathbf{\square})$ or $A \beta_{1-42}$ and 1 $\mu \mathrm{g} / \mathrm{ml}$ polymyxin $B(\square)$. Values are means \pm SD from triplicate experiments performed 4 times, $n=12$. (B) The concentrations of TNF produced by RAW 264 cells pre-treated with control medium ( $\bullet$ ) $5 \mu \mathrm{M}$ glimepiride (o) or $5 \mu \mathrm{M}$ glipizide ( $\square$ ) and incubated with $A \beta_{1-42}$. Values are means $\pm S D$ from triplicate experiments performed 4 times, $n=12$. (C) The concentrations of IL-1 $\beta$ produced by RAW 264 cells pre-treated with control medium (•) $5 \mu \mathrm{M}$ glimepiride (o) or $5 \mu \mathrm{M}$ glipizide ( $\square$ ) and incubated with $A \beta_{1-42}$. Values are means $\pm S D$ from triplicate experiments performed 4 times, $n=12$. (D) The concentrations of IL-6 produced by RAW 264 cells pre-treated with control medium $(\bullet), 5 \mu \mathrm{M}$ glimepiride (o) or $5 \mu \mathrm{M}$ glipizide ( $\square$ ) and incubated with $A \beta_{1-42}$. Values are means $\pm S D$ from triplicate experiments performed 4 times, $n=12$. 

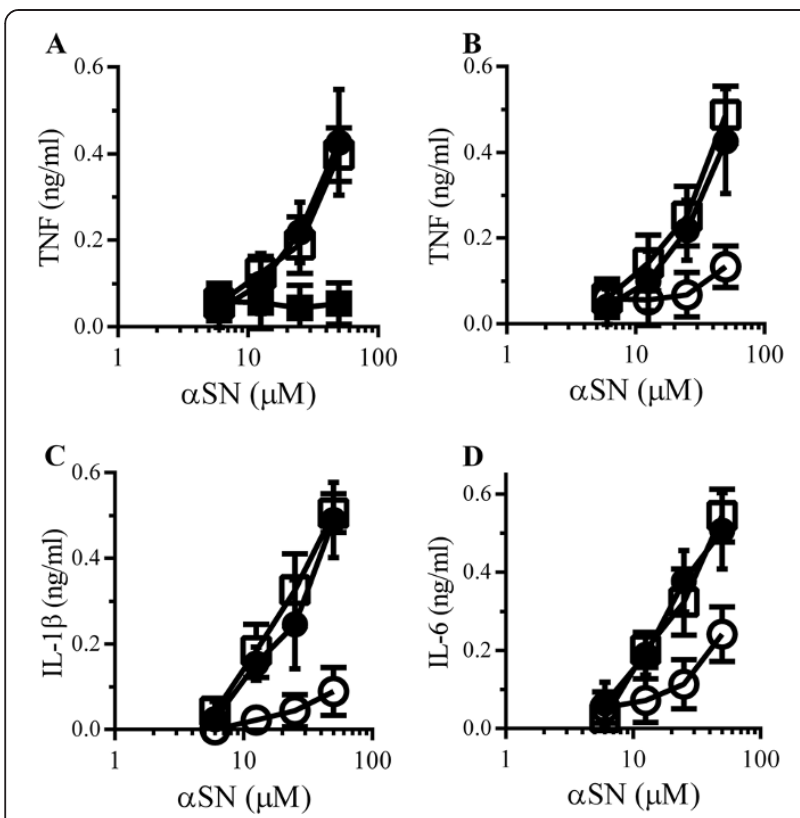

Figure 4 Glimepiride reduces cytokine secretion from RAW 264 cells incubated with aSN. (A) The concentrations of TNF produced

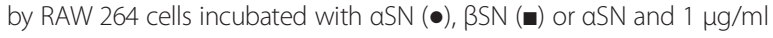
polymyxin $B(\square)$. Values are means \pm SD from triplicate experiments performed 4 times, $n=12$. (B) The concentrations of TNF produced by RAW 264 cells pre-treated with control medium $(\bullet), 5 \mu \mathrm{M}$ glimepiride (०) or $5 \mu \mathrm{M}$ glipizide ( $\square$ ) and incubated with aSN. Values are means \pm SD from triplicate experiments performed 4 times, $n=12$. (C) The concentrations of IL-1 $\beta$ produced by RAW 264 cells pre-treated with control medium (•) or $5 \mu \mathrm{M}$ glimepiride (o) or $5 \mu \mathrm{M}$ glipizide ( $\square$ ) and incubated with aSN. Values are means \pm SD from triplicate experiments performed 4 times, $n=12$. (D) The concentrations of $\mathrm{L}-6$ produced by RAW 264 cells pre-treated with control medium $(\bullet), 5 \mu \mathrm{M}$ glimepiride (o) or $5 \mu \mathrm{M}$ glipizide ( $\square$ ) and incubated with aSN. Values are means \pm SD from triplicate experiments performed 4 times, $n=12$.

Glimepiride reduced cytokine secretion from microglial cells Responses from RAW 264 cells were compared to those obtained with primary microglial cells which produced similar amounts of TNF when incubated with either 50 $\mu \mathrm{M}$ PrP82-146 or $50 \mu \mathrm{M} \mathrm{A} \beta_{1-42}$. The amounts of TNF secreted from microglial cells incubated with control peptides, PrP82-146scrambled or $A \beta_{42-1}$, were not significantly higher than those from control microglial cells (data not shown). Pre-treatment of microglial cells with $5 \mu \mathrm{M}$ glimepiride, but not $5 \mu \mathrm{M}$ glipizide, significantly reduced TNF secretion in response to $50 \mu \mathrm{M}$ PrP82-146 or $50 \mu \mathrm{M} \mathrm{A} \beta_{1-42}$ (Figure $5 \mathrm{~A}$ ). It was not clear whether soluble CD14 released from glimepiride-treated cells bound to $\operatorname{PrP}$ and $A \beta$ peptides, thus preventing their interaction with microglial cells, or whether glimepiride caused microglial cells to be hyporesponsive to $\operatorname{PrP}$ and $A \beta$ peptides. Therefore, microglial cells were treated with $5 \mu \mathrm{M}$ glimepiride for 1 hour and then thoroughly washed to remove any soluble receptors before the
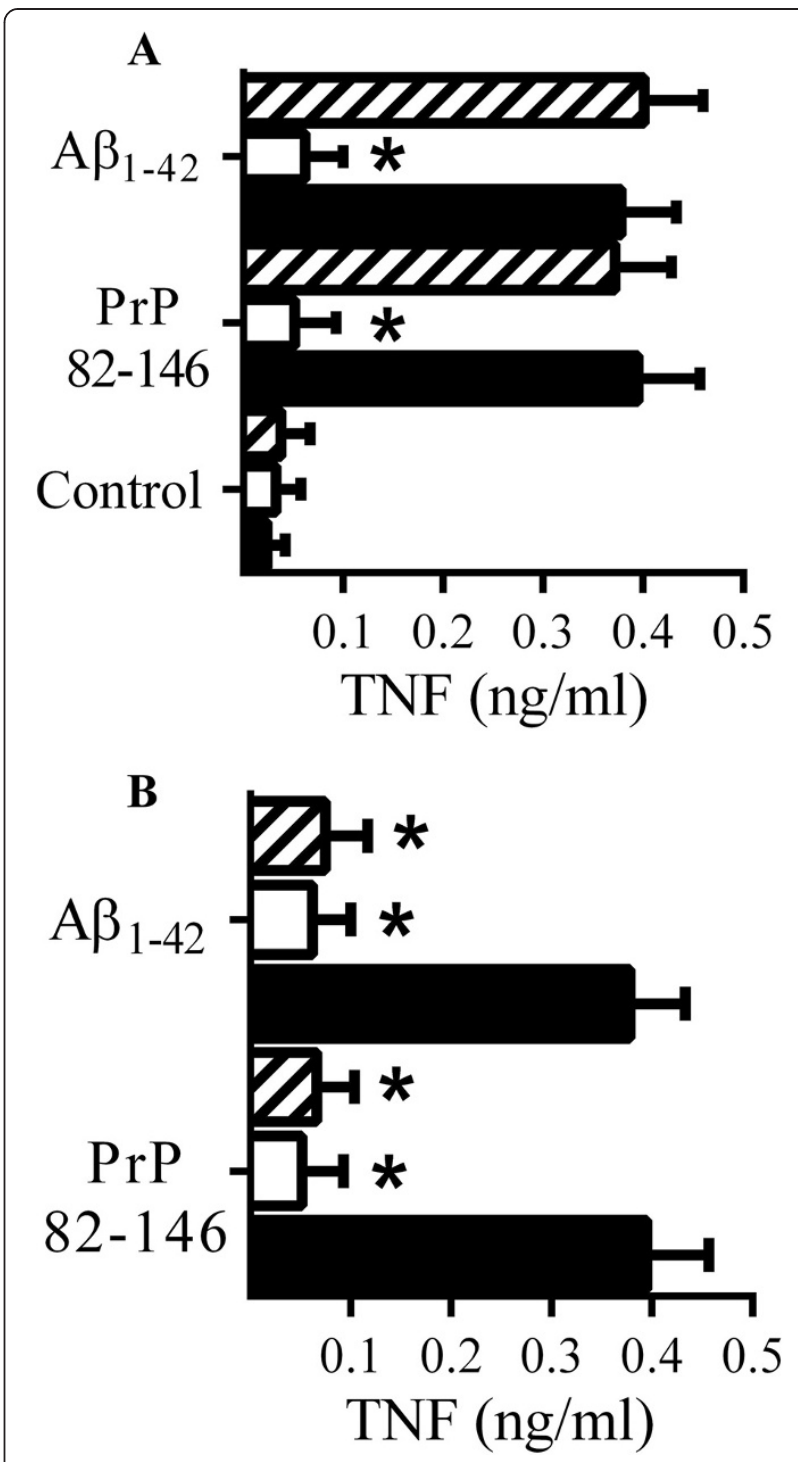

Figure 5 Glimepiride reduces cytokine secretion from microglial cells incubated with PrP82-146 or $A \beta_{1-42}$. (A) The concentrations of TNF produced by microglial cells pre-treated for 1 hour with control medium (घ), $5 \mu \mathrm{M}$ glimepiride ( $\square$ ) or $5 \mu \mathrm{M}$ glipizide (striped bars) and incubated with control medium, $50 \mu \mathrm{M}$ PrP82-146 or $50 \mu \mathrm{M} A \beta_{1-42}$ as shown. Values are means \pm SD from triplicate experiments performed 3 times, $n=9$. ${ }^{*} T N F$ significantly less than control cells incubated with peptides. (B) The concentrations of TNF produced by microglial cells pre-treated with control medium $(\bullet)$ or $5 \mu \mathrm{M}$ glimepiride for 1 hour ( $\square$ ), or pre-treated with $5 \mu \mathrm{M}$ glimepirde for 1 hour and washed 3 times with PBS (striped bars) and incubated with $50 \mu \mathrm{M}$ PrP82-146 or $50 \mu \mathrm{M} A \beta_{1-42}$ as shown. Values are means \pm SD from triplicate experiments performed 3 times, $n=9$. *TNF significantly less than control cells incubated with peptides.

addition of $50 \mu \mathrm{M}$ PrP82-146 or $50 \mu \mathrm{M} \mathrm{A} \beta_{1-42 .}$. We report that washed cells produced less TNF than control cells when incubated with $50 \mu \mathrm{M}$ PrP82-146 or $50 \mu \mathrm{M}$ $\mathrm{A} \beta_{1-42}$ (Figure 5B). 
Immunosuppressive effects of glimepiride are transient A time course study was used to determine whether the effects of glimepiride on RAW 264 and microglial cells were permanent. After treatment with $5 \mu \mathrm{M}$ glimepiride, there was a time-dependent increase in cell-associated CD14 in both RAW 264 cells (Figure 6A) and microglial cells (Figure 6C). Similarly, the capacity of RAW 264 and microglial cells to produce TNF in response to PrP82-146 also showed a time-dependent increase (Figures 6B and D).

\section{Glimepiride reduced LPS-induced cytokine secretion}

The effect of glimepiride on cytokine secretion from RAW 264 cells incubated with LPS was also examined. The addition of LPS caused a dose-dependent increase in the secretion of TNF, IL- $1 \beta$ and IL- 6 which was reduced by pre-treatment with $5 \mu \mathrm{M}$ glimepiride (Figure 7A, B and C). In contrast, cytokine secretion was not affected by pre-treatment with $5 \mu \mathrm{M}$ glipizide. Similarly, pre-treatment with $5 \mu \mathrm{M}$ glimepiride, but not 5
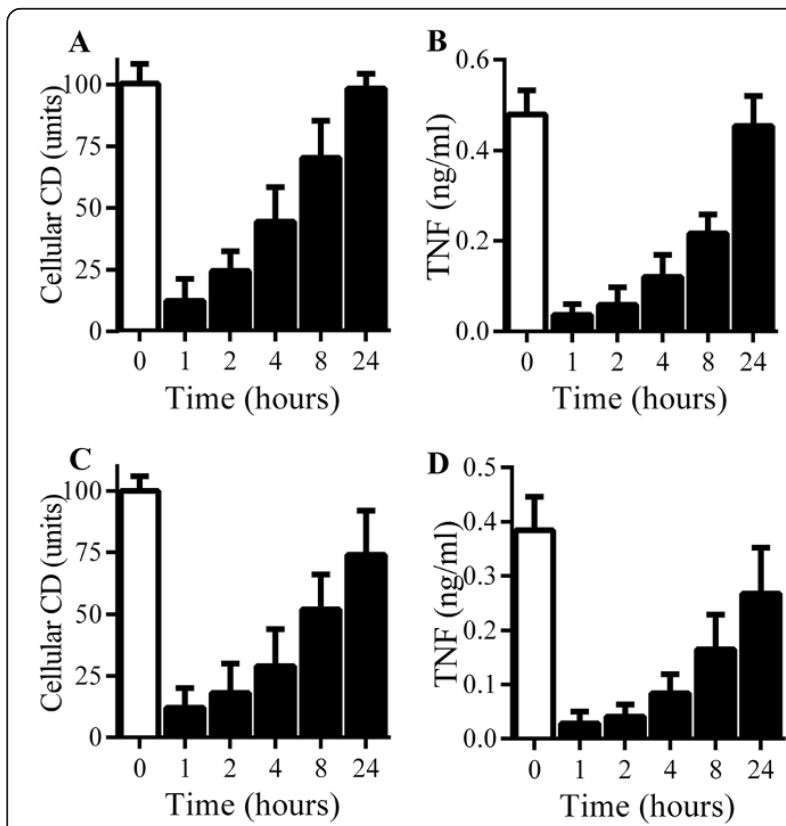

Figure 6 RAW264 and microglial cells recover from glimepiride-induced suppression of cytokine production. (A)

The amounts of CD14 in RAW 264 cells treated with control medium ( $\square$ ) or $5 \mu \mathrm{M}$ glimepiride for time periods as shown (ם). Values are means \pm SD from triplicate experiments performed twice, $n=6$. (B) The concentrations of TNF produced by RAW 264 cells pre-treated with control medium ( $\square$ ) or $5 \mu \mathrm{M}$ glimepiride for time periods as shown ( $\mathbf{\square})$ and incubated with $50 \mu \mathrm{M}$ PrP82-146 for 24 hours. Values are means \pm SD from triplicate experiments performed twice, $n=6$. (C) The amounts of CD14 in microglial cells treated with control medium ( $\square$ ) or $5 \mu \mathrm{M}$ glimepiride for time periods as shown (घ). Values are means \pm SD from triplicate experiments performed twice, $n=6$. (D) The concentrations of TNF produced by microglial cells pre-treated with control medium ( $\square$ ) or $5 \mu \mathrm{M}$ glimepiride for time periods as shown (-) and incubated with $50 \mu \mathrm{M}$ PrP82-146 for 24 hours. Values are means \pm SD from triplicate experiments performed twice, $n=6$.
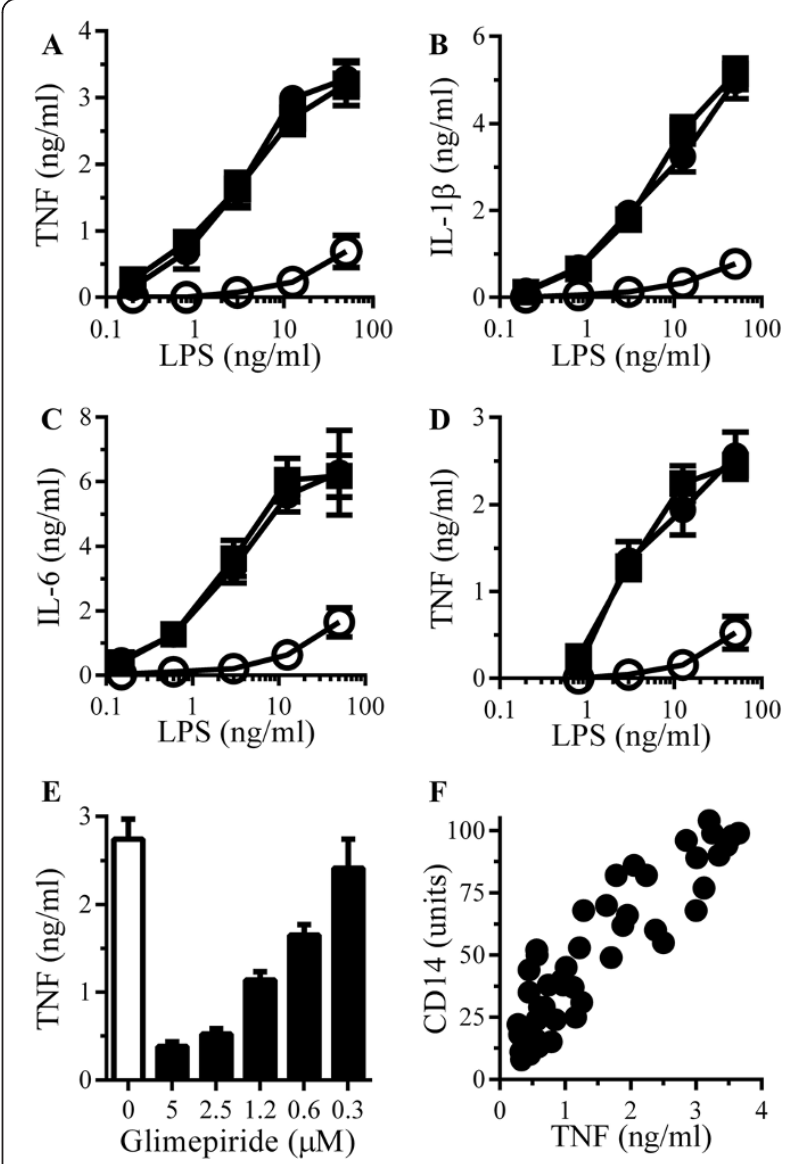

F

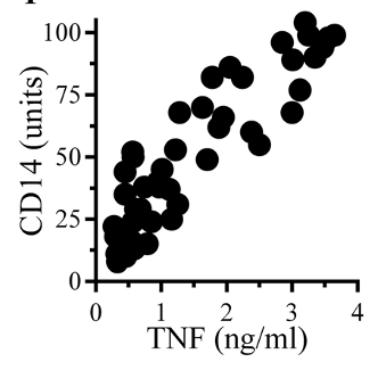

Figure 7 Glimepiride reduces lipopolysaccharide (LPS)-induced cytokine secretion. (A) The concentrations of TNF produced by RAW 264 cells pre-treated with control medium (•), $5 \mu \mathrm{M}$ glimepiride (o) or $5 \mu \mathrm{M}$ glipizide ( $\mathbf{\square}$ ) and incubated with LPS. Values are means \pm SD from triplicate experiments performed 4 times, $n=12$. (B) The

concentrations of IL-1 $\beta$ produced by RAW 264 cells pre-treated with control medium (•), $5 \mu \mathrm{M}$ glimepiride (o) or $5 \mu \mathrm{M}$ glipizide (घ) and incubated with LPS. Values are means \pm SD from triplicate experiments performed 4 times, $n=12$. (C) The concentrations of IL-6 produced by RAW 264 cells pre-treated with control medium $(\bullet), 5 \mu \mathrm{M}$ glimepiride (o) or $5 \mu \mathrm{M}$ glipizide ( $\mathbf{a}$ ) and incubated with LPS. Values are means \pm SD from triplicate experiments performed 4 times, $n=12$. (D) The concentrations of TNF produced by microglial cells pre-treated with

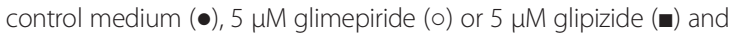
incubated with LPS. Values are means \pm SD from triplicate experiments performed 4 times, $n=12$. (E) The concentrations of TNF produced by RAW 264 cells pre-treated with control medium ( $\square$ ) or glimepiride as shown ( $\mathbf{\square}$ ) and incubated with $10 \mathrm{ng} / \mathrm{ml}$ LPS. Values are means \pm SD from triplicate experiments performed 3 times, $n=9$. (F) There was a significant correlation between the CD14 content of RAW 264 cells treated with glimepiride $(0.3$ to $5 \mu \mathrm{M})$ and the concentrations of TNF produced in response to $10 \mathrm{ng} / \mathrm{ml}$ LPS, Pearson's coefficient $=0.886$.

$\mu \mathrm{M}$ glipizide, reduced TNF production from primary microglial cells incubated with LPS (Figure 7D). When RAW 264 cells were pre-treated with different concentrations of glimepiride before the addition of $10 \mathrm{ng} / \mathrm{ml}$ LPS, glimepiride reduced TNF secretion in a dosedependent manner (Figure 7E). When concentrations of 
cellular CD14 after treatment with glimepiride (0.3 to $5 \mu \mathrm{M})$ were plotted against TNF production in response to LPS, a significant correlation was observed (Figure 7F).

\section{PI-PLC digestion reduced cytokine secretion from RAW 264 cells}

The molecular mechanisms of glimepiride-induced immunosuppression were examined. Since glimepiride activates an endogenous GPI-PLC causing the release of GPIanchored proteins $[34,35]$, we hypothesised that treatment with PI-PLC would have similar effects to glimepiride on macrophages. Treatment of RAW 264 cells with 0.2 units PI-PLC/ml for 1 hour significantly reduced the amount of cell associated CD14 (7 units \pm 3 compared with $100 \pm 10$, $\mathrm{n}=9, P<0.05)$ and increased the amount of CD14 in cell supernatants (81 units \pm 6 compared with 7 units \pm $4, \mathrm{n}=9, P<0.05)$, thus replicating some of the effects of glimepiride upon RAW 264 cells. Critically, RAW 264 cells pre-treated with of 0.2 units/ml PI-PLC for 1 hour produced significantly less TNF, Il-1 $\beta$ and IL- 6 when incubated with $50 \mu \mathrm{M}$ PrP82-146, $\mathrm{A} \beta_{1-42}$ or $\alpha \mathrm{SN}$ than did vehicle-treated cells (Figure 8A, B and C). These
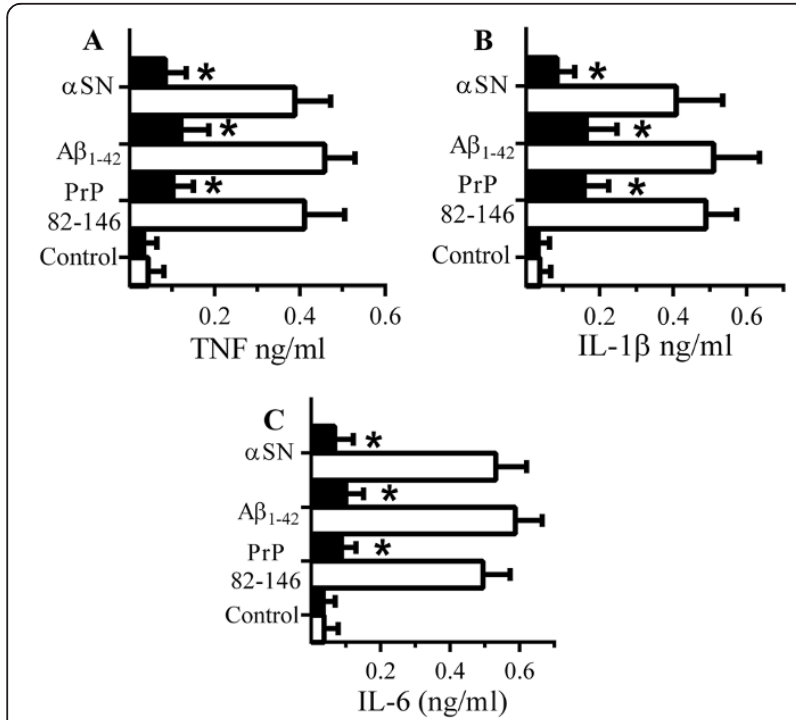

Figure 8 PI-PLC digestion reduced cytokine secretion from RAW 264 cells. (A) The concentrations of TNF produced by RAW 264 cells pre-treated with control medium ( $\square$ ) or PI-PLC ( $\mathbf{\square}$ ) and incubated with $50 \mu \mathrm{M}$ PrP82-146, $A \beta_{1-42}$ or aSN. Values are means \pm SD from triplicate experiments performed 4 times, $n=12$. ${ }^{*} T N F$ significantly less than control cells incubated with peptides. (B) The concentrations of IL-1 $\beta$ produced by RAW 264 cells pre-treated with control medium () or PI-PLC ( $\mathbf{\square}$ ) and incubated with $50 \mu \mathrm{M}$ PrP82-146, $A \beta_{1-42}$ or aSN. Values are means \pm SD from duplicate experiments performed 4 times, $n=8$. ${ }^{*} L-1 \beta$ significantly less than control cells incubated with peptides. (C) The concentrations of IL-6 produced by RAW 264 cells pre-treated with control medium ( $\square$ ) or PI-PLC (- and incubated with $50 \mu \mathrm{M}$ PrP82-146, $A \beta_{1-42}$ or aSN. Values are means $\pm S D$ from duplicate experiments performed 4 times, $n=8$. * $\mid L-6$ significantly less than control cells incubated with peptides. *IL-6 significantly less than control cells incubated with peptides. cells also produced less TNF, IL-1 $\beta$ and IL-6 in response to LPS (Figure 9A, B and C).

Next, we sought to reverse the effect of glimepiride by inhibiting the activity of GPI-PLC. The effects of pCMPS (an inhibitor of GPI-PLC [37]) upon glimepirideinduced suppression of cytokine production were studied. Treatment with $200 \mu \mathrm{M}$ p-CMPS did not affect the amount of CD14 in RAW 264 cells (94 units \pm 11 compared with $100 \pm 8, \mathrm{n}=9, P=0.5$ ), nor did it affect TNF secretion from RAW 264 cells incubated with $10 \mathrm{ng} / \mathrm{ml}$ LPS $(2,614 \mathrm{pg} / \mathrm{ml} \pm 338$ compared with $2,549 \mathrm{pg} / \mathrm{ml} \pm 306$, $\mathrm{n}=9, P=0.7$ ). However, the addition of $200 \mu \mathrm{M}$ p-CMPS to RAW 264 cells reversed the effect of glimepiride on cells, it prevented the glimepiride-induced reduction in cellular CD14 (Figure 10A) and reduced the glimepiride-induced suppression of TNF secretion in response to PrP82-146, $\mathrm{A} \beta_{42}$ and $\alpha \mathrm{SN}$ (Figure 10B) or LPS (Figure 10C). Primary microglial cells behaved in a similar manner to the RAW 264 cells in that the glimepiride-induced suppression of PrP82-146 and $A \beta_{42}$-TNF production was reversed by the inclusion of $200 \mu \mathrm{M}$ p-CMPS (Figure 10D).
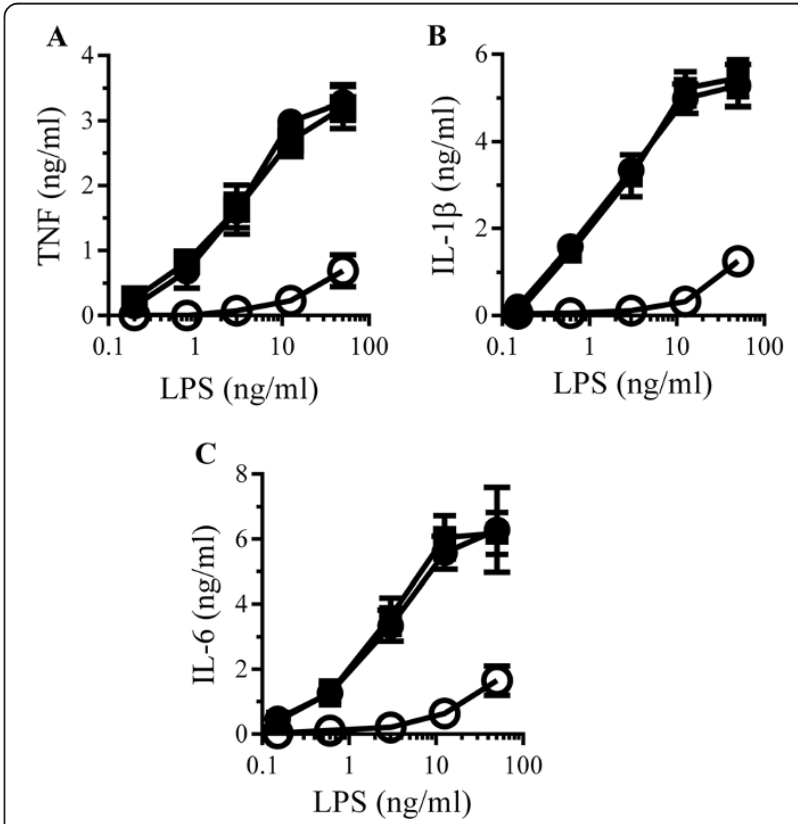

Figure 9 RAW 264 cells digested with PI-PLC are hyporesponsive to lipopolysaccharide (LPS). (A) The concentrations of TNF produced by RAW 264 cells pre-treated with control medium (•), PI-PLC (o) or heat-inactivated PI-PLC ( $\mathbf{\square})$ and incubated with LPS. Values are means \pm SD from triplicate experiments performed 4 times, $n=12$. (B) The concentrations of IL-1 $\beta$ produced by RAW 264 cells pre-treated with control medium (•), PI-PLC (o) or heat-inactivated PI-PLC (घ) and incubated with LPS. Values are means \pm SD from triplicate experiments performed 4 times, $n=12$. (C) The concentrations of IL-6 produced by RAW 264 cells pre-treated with control medium (•), PI-PLC (0) or heatinactivated PI-PLC (- $)$ and incubated with LPS. Values are means \pm SD from triplicate experiments performed 4 times, $n=12$. 


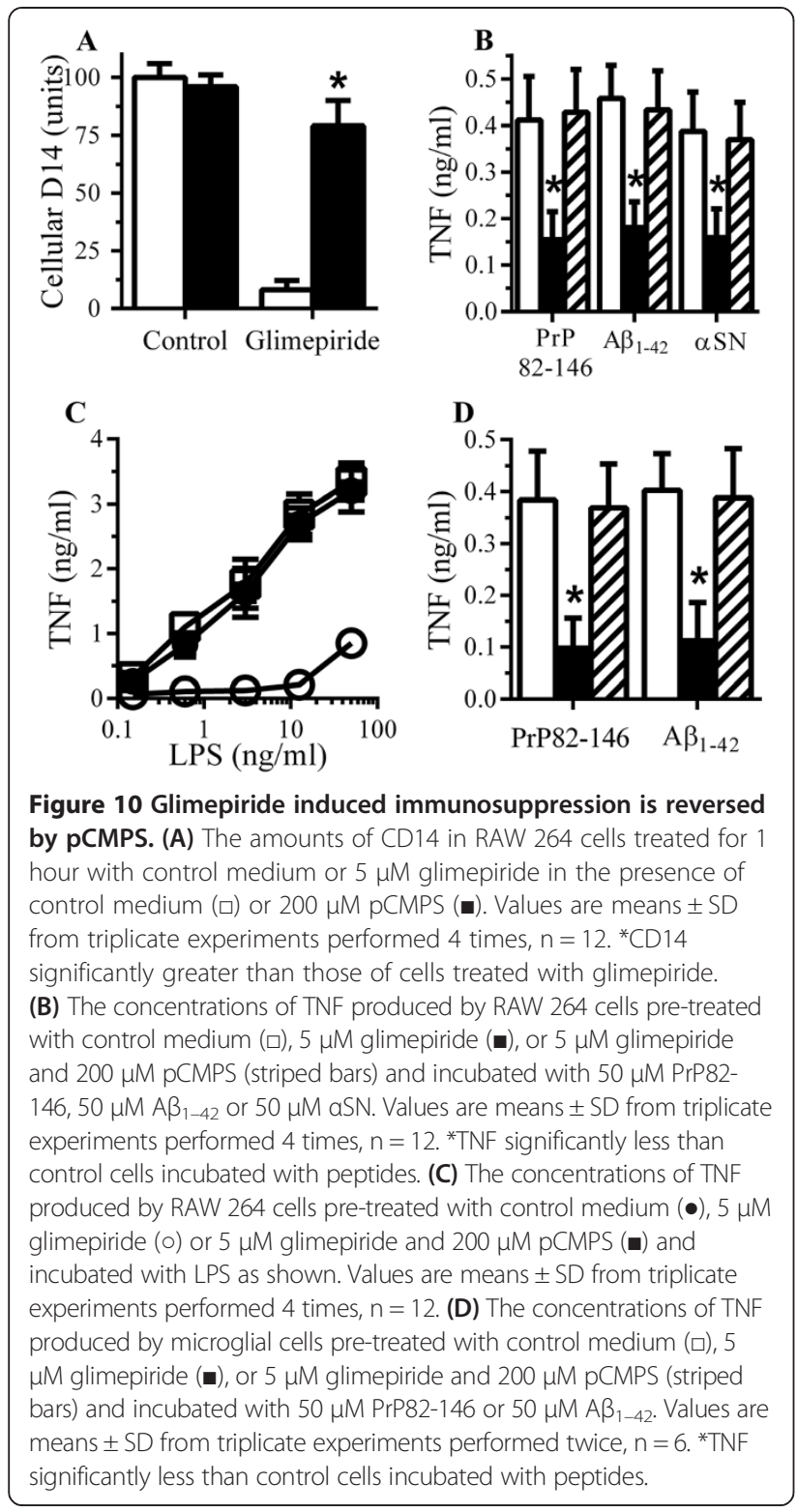

CD14 is involved in peptide-induced cytokine secretion

These results are consistent with the hypothesis that the inhibitory effects of glimepiride on cytokine secretion were mediated through a GPI-anchored protein, and while CD14 is known to be involved in LPS-induced cytokine secretion [25], other GPI-anchored proteins such as the cellular prion protein $\left(\operatorname{PrP}^{\mathrm{C}}\right)$ and $\mathrm{CD} 55$ may also be involved in the activation of macrophages $[26,38]$. To determine which of these receptors were critical for peptide-induced cytokine production RAW 264 cells were pre-treated with antibodies to CD14, $\operatorname{Pr} P^{C}$ or CD55. Pre-treatment of RAW 264 cells with antiserum to $\mathrm{CD} 14$ but not by antiserum to $\operatorname{PrP}^{\mathrm{C}}$ or to CD55 reduced TNF secretion from RAW 264 cells incubated with PrP82-146, $\mathrm{A} \beta_{42}$ or $\alpha \mathrm{SN}$ (Figure 11A) indicating that CD14 is a major receptor involved in peptide-induced TNF secretion. This hypothesis was strengthened by observations that microglial cells derived from CD14 knockout mice produced less TNF than microglial cells derived from CD14 wild type mice

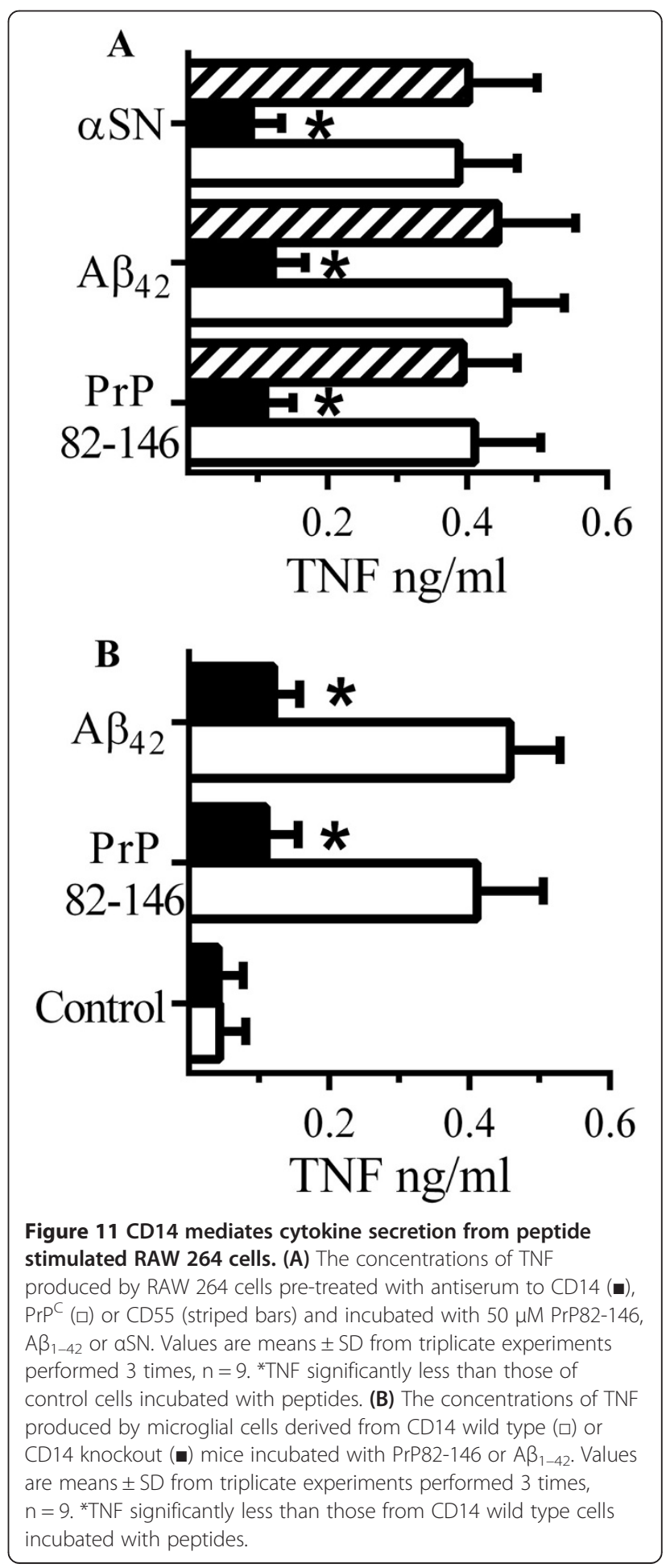


when incubated with PrP82-146 or $\mathrm{A} \beta_{42}$ (Figure 11B). Notably, TNF secretion from microglial cells derived from $\operatorname{PrP}^{\mathrm{C}}$ knockout mice was not significantly different from microglia derived from Prnp wild type mice when incubated with PrP82-146 or $\mathrm{A} \beta_{42}$ (data not shown).

Our results suggest that the immunosuppressant effects of glimepiride were mediated by the reduced expression of CD14, a molecule that acts as a receptor for LPS and neurotoxic peptides associated with prion, Alzheimer's disease and Parkinson's disease. To determine if glimepiride reduced the uptake of neurotoxic peptides to RAW 264 cells, glimepiride-treated cells were incubated with $50 \mu \mathrm{M}$ PrP82-146 or $50 \mu \mathrm{M} \mathrm{A} \beta_{42}$ for 2 hours. Pre-treatment with $5 \mu \mathrm{M}$ glimepiride did not significantly alter the concentration of PrP82-146 (43 $\mu \mathrm{M} \pm 5$ compared with $41 \mu \mathrm{M} \pm 7, \mathrm{n}=9, P=0.5$ ) or $\mathrm{A} \beta_{42}(39 \mu \mathrm{M} \pm 8$ compared with $40 \mu \mathrm{M} \pm 7, \mathrm{n}=9, P=0.7)$ in RAW 264 cells.

Peptides cause the translocation of TLR-4 into membrane rafts Since signalling complexes formed around CD14 also include TLR-4 [26], the effects of macrophage stimulants upon TLR-4 was studied. Firstly we showed that the amounts of TLR-4 in RAW-264 cells were not significantly altered by the addition of either $50 \mu \mathrm{M}$ PrP82-146 (100 units \pm 5 compared with 98 units $\pm 7, \mathrm{n}=9, P=0.62$ ) or $50 \mu \mathrm{M} \mathrm{A} \beta_{42}$ (100 units \pm 5 compared with 97 units \pm 8 , $\mathrm{n}=9, P=0.49$ ). The formation of signalling complexes involves the recruitment of TLR-4 into specific detergentresistant membranes commonly called lipid rafts $[39,40]$. Here we show that the addition of PrP82-146, but not the control peptide (PrP82-146scrambled), caused a dosedependent increase in the amounts of TLR-4 within (DRMs) rafts (Figure 12A). The amounts of TLR-4 in rafts was also increased after the addition of $50 \mu \mathrm{M} \mathrm{A} \beta_{1-42}$ or $\alpha \mathrm{SN}$, but were not affected by $50 \mu \mathrm{MA} \beta_{42-1}$ or $\beta S N$ (Figure 12B). After RAW 264 cells were incubated with different concentrations of PrP82-146, $\mathrm{A} \beta_{1-42}$ or $\alpha \mathrm{SN}$ there was a significant correlation between the amounts of TLR-4 within rafts and the amounts of TNF produced (Figure 12C). Similar results were obtained when RAW264 cells were incubated with LPS; namely that LPScaused TLR- 4 to migrate into rafts and that there was a significant correlation between the amounts of TLR- 4 in rafts and TNF production (Figure 12D).

\section{Glimepiride reduces the peptide-induced translocation of TLR-4 into membrane rafts}

Treatment of RAW264 cells with $5 \mu \mathrm{M}$ glimepiride did not affect the amounts of TLR-4 either in whole cells (100 units \pm 5 compared with 99 units $\pm 7, \mathrm{n}=9, P=$ 0.71 ) or within DRMs (rafts) (21 units \pm 3 compared with 20 units $\pm 6, \mathrm{n}=9, P=0.58$ ). Next, we showed that pre-treatment with $5 \mu \mathrm{M}$ glimepiride reduced the
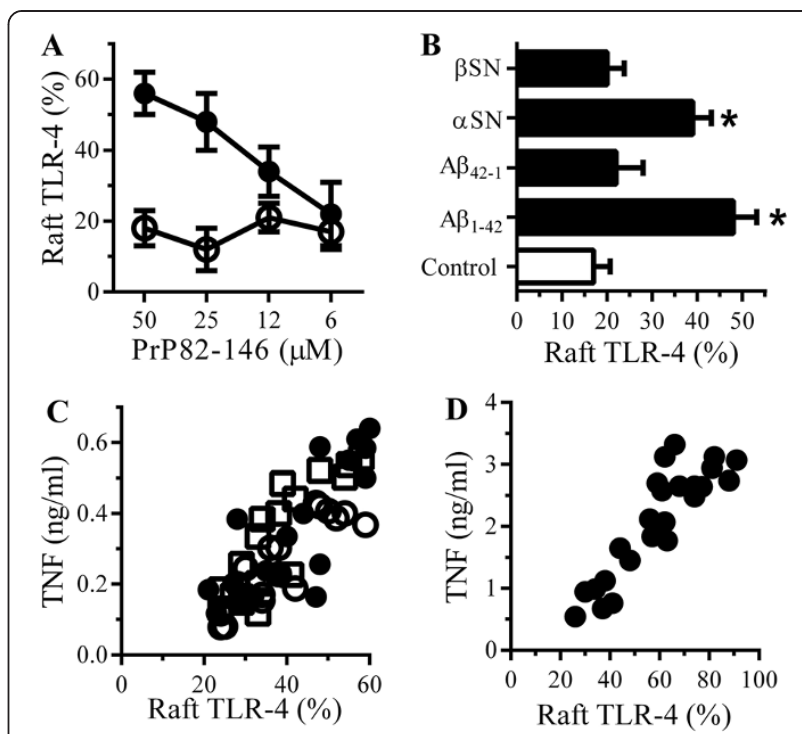

Figure 12 PrP82-146 causes the translocation of Toll-like receptor (TLR)-4 into rafts. (A) The \% of TLR-4 in DRMs derived from RAW 264 cells treated with PrP82-146 (•) or PrP82-146scrambled (o). Values are means \pm SD from triplicate experiments performed 3 times, $n=9$. (B) The \% TLR-4 in DRMs derived from RAW 264 cells treated with control medium (口) or $50 \mu \mathrm{M} A \beta_{1-42}$, $A \beta_{42-1}$, aSN or $\beta S N$ as shown (-). Values are means \pm SD from triplicate experiments performed 3 times, $n=9$. *TLR-4 significantly greater than those of control cells. (C) RAW 264 cells were incubated with PrP82-146 (०), $A \beta_{1-42}(\bullet)$ or aSN (口) (6 to $50 \mu \mathrm{M})$. There were significant correlations between $\%$ TLR-4 in rafts and TNF for PrP82-146, Pearson's coefficient $=0.88, A \beta_{1-42}$, Pearson's coefficient $=0.78$ and aSN Pearson's coefficient $=0.86$. (D) There was a significant correlation between the \% TLR- 4 in rafts of RAW 264 cells incubated with lipopolysaccharide (LPS) $(0.75$ to $50 \mathrm{ng} / \mathrm{ml})$ and TNF produced, Pearson's coefficient $=0.887$.

amounts of TLR-4 in rafts in cells incubated with $50 \mu \mathrm{M}$ PrP82-146 (Figure 13A), $50 \mu \mathrm{M} \mathrm{A} \beta_{1-42}$ (Figure 13B), 50 $\mu \mathrm{M} \alpha \mathrm{SN}$ (Figure 13C) or $10 \mathrm{ng} / \mathrm{ml}$ LPS (Figure 13D). Pre-treatment of RAW 264 cells with $5 \mu \mathrm{M}$ glipizide did not affect either peptide or LPS-induced translocation of TLR-4 into DRMs.

\section{Discussion}

There is accumulating evidence that inflammation exacerbates the symptoms and accelerates the progression of $\mathrm{AD}$ and PD [10-12]. Consequently, glial cells activated by aggregated proteins are seen as a therapeutic target. Here we show that physiologically relevant concentrations of glimepiride [41] result in the release of several GPI-anchored proteins from RAW 264 and microglial cells consistent with reports that this drug activates an endogenous GPI-PLC [33,34]. Glimepiride treatment of RAW 264 cells also resulted in lower concentrations of cytokine secretion when these cells were incubated with PrP82-146, $A \beta_{42}$ or $\alpha \mathrm{SN}$.

The role of cytokines in neurodegenerative diseases is controversial, although TNF has been reported to protect 


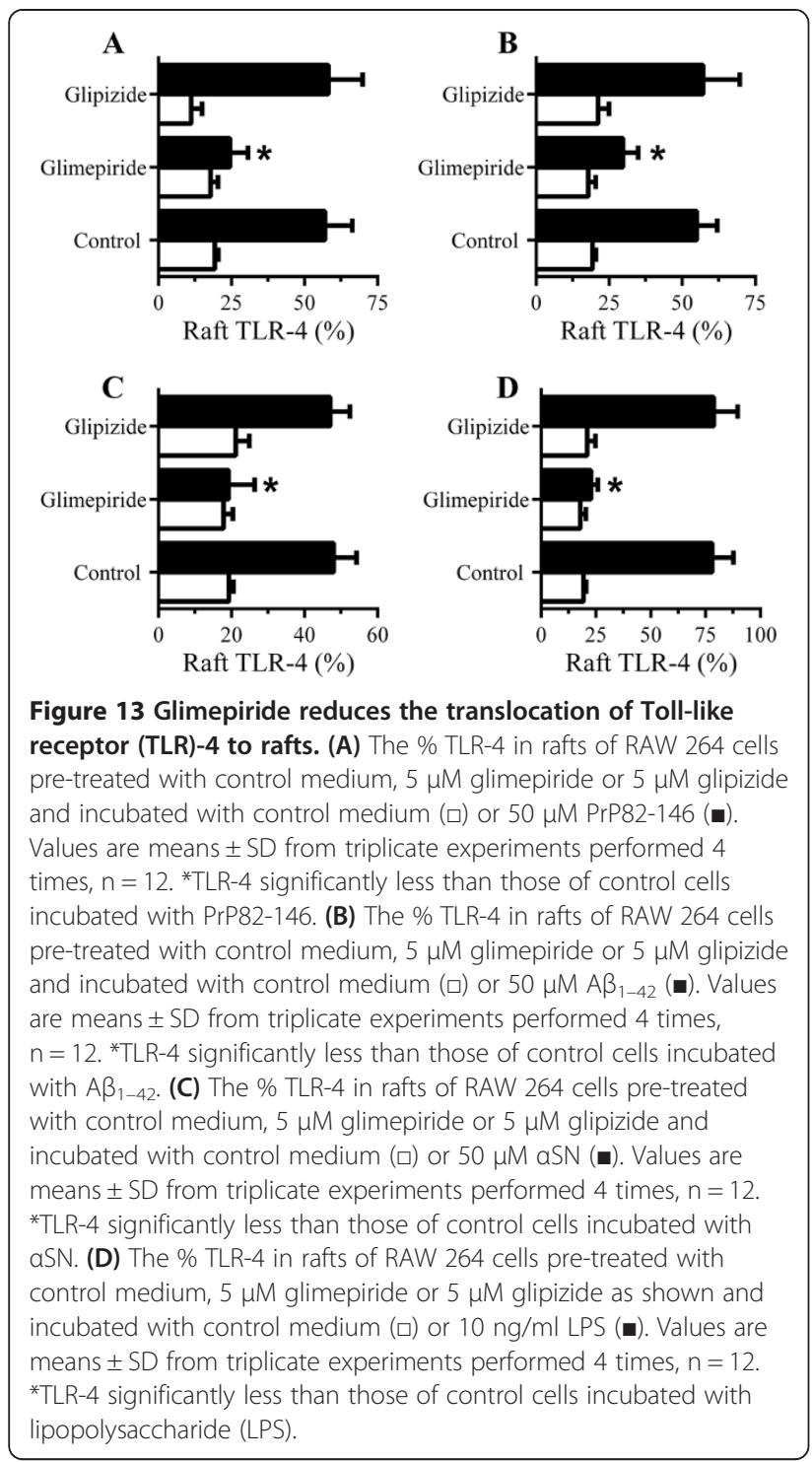

neurons against $A \beta[42,43]$ the majority of studies suggest that elevated concentrations of cytokines increase neurodegeneration. Thus, elevated levels of TNF are reported in neurodegenerative conditions including $\mathrm{AD}$ and $\mathrm{PD}$ [44,45], inhibition of TNF prevents neuropathology in mouse models of $\mathrm{AD}$ and post-operative cognitive decline $[46,47]$ and the TNF inhibitor etanercept causes cognitive improvement in AD patients [48]. Similarly, high levels of IL-6 are raised in the brain tissue or cerebrospinal fluid (CSF) in AD, AIDS dementia complex, multiple sclerosis, stroke, PD and traumatic brain injuries [49] and IL-6 receptors are expressed on neurons at synapses and can regulate neurotransmitter release [50,51]. As a consequence of these observations it is thought that compounds that reduce cytokine production are likely to reduce neurodegeneration.
As glimepiride would be expected to decrease the expression of many GPI-anchored proteins, including $\mathrm{CD} 14, \operatorname{Pr} \mathrm{P}^{\mathrm{C}}$ and $\mathrm{CD} 55$ - proteins which are implicated/ involved in cytokine production $[25,26,52]$ - it was not clear which GPI-anchored protein was responsible for cellular responses to aggregated peptides. However we found that CD55 expression was not affected by glimepiride and that antiserum to CD55 did not affect peptide-induced cytokine production. Although glimepiride reduced the $\operatorname{PrP}^{\mathrm{C}}$ content of RAW 264 cells, cytokine production was not affected by antiserum to $\operatorname{PrP}^{\mathrm{C}}$. In contrast, antiserum to CD14 blocked peptide- and LPS-induced cytokine production. In addition, microglia from CD14 knockout mice produced fewer cytokines than microglia from CD14 wild type mice when incubated with PrP82-146 or $A \beta_{1-42}$. Collectively, these results indicate that it is the loss of CD14 that is the key element in glimepiride-induced suppression of cytokine production. The loss of CD14 from glimepiride-treated cells was accompanied by a corresponding increase of CD14 in cell supernatants, showing that CD14 was released from cells rather than degraded.

The expression of CD14 is increased in animal models of AD and PD [53] and CD14 is involved in microglial recognition to $A \beta$ fibrils [16] and prion-damaged neurons [24]. Although pre-treatment with glimepiride significantly reduced the amounts of TNF and IL- 6 produced by RAW 264 and microglial cells incubated with PrP82-146, $\alpha \mathrm{SN}$ or $\mathrm{A} \beta_{42}$, it did not reduce the binding of PrP82-146 or $A \beta_{42}$ to RAW 264 cells. Thus, although the presence of soluble CD14 in cell supernatants may bind to $\operatorname{PrP}$ or $\mathrm{A} \beta$ peptides, such complexes still interacted with cells. Furthermore, cells treated with glimepiride and then washed, so as to remove any soluble CD14, remained hyporesponsive to $\operatorname{PrP}$ and $A \beta$ peptides indicating that soluble $\mathrm{CD} 14$ alone was not sufficient to explain the immunosuppressive effects of glimepiride. These observations indicate that although cells bind these peptides in a CD14-independent manner, cytokine production is dependent upon the engagement of CD14. Recently, the deletion of CD14 was shown to attenuate AD-like pathology in a transgenic murine model of $\mathrm{AD}$ [27] suggesting that $\mathrm{CD} 14$-dependent microglial responses to aggregated $A \beta$ are a major driver of the pathology in $\mathrm{AD}$.

Insulin-induced activation of a GPI-PLC generates second messengers that mediate the intracellular effects of insulin [54]. Since glimepiride mimics the effects of insulin upon GPI-PLC $[33,55]$, we hypothesise that it is the glimepiride-induced activation of an endogenous GPIPLC that leads to the release of CD14 and the suppression of cytokine production. This idea was supported by two observations; firstly, that RAW 264 cells digested with PI-PLC were similar to glimepiride-treated cells in that they contained less CD14 and secreted less 
cytokines than control cells. Secondly, the inclusion of p-CMPS, a selective inhibitor of GPI-PLC [37], reversed the effects of glimepiride on cellular levels of CD14 and cytokine production.

These observations may have implications beyond neurodegenerative diseases as the pathogenesis associated with many acute infectious diseases may be partly caused following excessive cytokine release by macrophages. For example, LPS is considered to be the major macrophage stimulant leading to excessive cytokine production in gram negative bacterial infections. CD14 was identified as a receptor that mediates LPS-induced cell activation [25] and in some animal models, CD14 knockout mice are resistant to acute septicaemia [56] suggesting that the induction of cytokines via a CD14dependent mechanism is critical for pathogenesis. Here we show that glimepiride treatment also reduced the LPS-induced secretion of TNF and IL-6. While these results suggest that the loss of CD14 was responsible for the hyporesponsive state of glimepiride-treated macrophages, we noted that glimepiride would be expected to decrease surface expression of other GPI-anchored proteins, and some of these might be responsible for LPSinduced responses. $\mathrm{PrP}^{\mathrm{C}}$ and $\mathrm{CD} 55$ are GPI-anchored proteins which have been implicated in LPS signalling [26]. The predominant role of CD14 in LPS-induced cytokine production in these experiments was demonstrated by both CD14 knockout microglia and neutralising antiserum to CD14.

As glimepiride did not reduce the binding of LPS or neurotoxic peptides to macrophages we investigated cell signalling in these cells. The binding of LPS to CD14 does not initiate cell activation alone; rather it is the first step in the formation of a signalling complex. Thus, CD14 acts as a co-receptor for TLR- 4 which mediates activation of myeloid cells [26]. CD14 is targeted to membrane rafts which, in quiescent cells, exist as microdomains ranging from 5 to $200 \mathrm{~nm}$ in diameter $[57,58]$ and which are 'poised' to form larger rafts [59] and coalesce under specific stimuli to form a larger signalling platform [57,59-62]. The coalescence of individual rafts may bring together receptors and signalling proteins into a functional complex; for example the LPS-induced formation of CD14:MD2:TLR-4 complexes [63]. Notably, this tri-receptor complex is necessary for activation of microglia by $A \beta$ [64] and TLR-4 is associated with increased cytokine production in murine $\mathrm{AD}$ models $[65,66]$.

The reorganisation of rafts in the outer membrane leaflet in response to external stimuli can result in the sorting of intracellular signalling molecules on the cytoplasmic leaflet [67-70] and consequently cell activation. For example, extracellular LPS has been shown to recruit the key signalling protein TLR-4 to rafts following engagement of specific receptors $[26,63,70]$ and activate intracellular signalling pathways leading to cytokine production. In this study we demonstrate that PrP82-146, $\mathrm{A} \beta_{1-42}$ or $\alpha \mathrm{SN}$ also caused the translocation of TLR-4 into rafts and that there was a significant correlation between the amounts of TLR-4 within rafts and cell activation as measured by cytokine production. Critically, this translocation of TLR-4 into rafts was reduced in cells treated with glimepiride.

\section{Conclusions}

Novel approaches of treating neurodegenerative conditions are urgently required. Here we show that glimepiride triggered the release of CD14 from RAW 264 cells consistent with activation of an endogenous GPI-PLC and the shedding of GPI-anchored proteins including CD14 from RAW 264 cells. Consequently, glimepiride treatment significantly reduced cytokine secretion from RAW 264 cells incubated with PrP82-146, $A \beta_{1-42}$ or $\alpha \mathrm{SN}$. Such observations suggest that glimepiride may reduce cytokine secretion and hence neuroinflammation in neurodegenerative diseases and should be considered as a novel adjunctive treatment for $\mathrm{AD}$.

\section{Abbreviations \\ AD: Alzheimer's disease; AB: amyloid- $\beta$; $a S N$ : $\alpha$-synuclein; CSF: cerebrospinal fluid; DRM: detergent resistant membrane; EDTA: ethylenediaminetetraacetic acid; ELISA: enzyme-linked-immunoassay; FCS: foetal calf serum; \\ GPI: glycosylphosphatidylinositol; Ig: immunoglobulin; IL: interleukin; LPS: lipopolysaccharide; p-CMPS: p-chloromercuriphenylsulphonate; PBS: phosphate-buffered saline; PD: Parkinson's disease; PI: phosphatidylinositol; PLC: phospholipase C; PrPC: cellular prion protein; SDS: sodium dodecyl sulphate; TLR: Toll-like receptor; TNF: tumour necrosis factor.}

\section{Competing interests}

The authors declare that there are no competing interests.

\section{Authors' contributions}

VI: data collection and analysis and manuscript revision. CB: conception and design, data collection and analysis, manuscript writing and revision. AW: conception and design and manuscript writing and revision. All authors read and approved the final manuscript.

\section{Acknowledgements}

This work was supported by the European Commission FP6 'Neuroprion' Network of Excellence and the Royal Veterinary College Bioveterinary Science undergraduate Research projects. We thank Dr Mourad Tayebi for the mAbs ICSM18.

\section{Author details}

'Department of Pathology and Pathogen Biology, Royal Veterinary College, Hawkshead Lane, North Mymms, Herts, London, UK. ${ }^{2}$ Department of Veterinary Medicine, University of Cambridge, Madingley Road, Cambridge CB3 OES, UK.

Received: 21 March 2014 Accepted: 4 June 2014

Published: 21 June 2014

\section{References}

1. Schlachetzki JC, Hull M: Microglial activation in Alzheimer's disease. Curr Alzheimer Res 2009, 6(6):554-563.

2. Stalder M, Phinney A, Probst A, Sommer B, Staufenbiel M, Jucker M: Association of microglia with amyloid plaques in brains of APP23 transgenic mice. Am J Pathol 1999, 154(6):1673-1684. 
3. Zhang W, Wang T, Pei Z, Miller DS, Wu X, Block ML, Wilson B, Zhang W, Zhou Y, Hong J-S, Zhang J: Aggregated a-synuclein activates microglia: a process leading to disease progression in Parkinson's disease. FASEB $J$ 2005, 19(6):533-542

4. Combs CK, Karlo JC, Kao SC, Landreth GE: $\beta$-Amyloid stimulation of microglia and monocytes results in TNFalpha-dependent expression of inducible nitric oxide synthase and neuronal apoptosis. J Neurosci 2001, 21(4):1179-1188.

5. Klegeris A, Walker DG, McGeer PL: Interaction of Alzheimer beta-amyloid peptide with the human monocytic cell line THP-1 results in a protein kinase C-dependent secretion of tumor necrosis factor-alpha. Brain Res 1997, 747(1):114-121.

6. Jin J, Shie FS, Liu J, Wang Y, Davis J, Schantz AM, Montine KS, Montine TJ, Zhang J: Prostaglandin E2 receptor subtype 2 (EP2) regulates microglial activation and associated neurotoxicity induced by aggregated alphasynuclein. J Neuroinflammation 2007, 4:2.

7. Eikelenboom P, Bate C, Van Gool WA, Hoozemans JJ, Rozemuller JM Veerhuis R, Williams A: Neuroinflammation in Alzheimer's disease and prion disease. Glia 2002, 40:232-239.

8. Perry VH, Cunningham C, Holmes C: Systemic infections and inflammation affect chronic neurodegeneration. Nat Rev Immunol 2007, 7(2):161-167.

9. Wyss-Coray T: Inflammation in Alzheimer disease: driving force, bystander or beneficial response? Nat Med 2006, 12(9):1005-1015.

10. Breitner JCS, Haneuse SJPA, Walker R, Dublin S, Crane PK, Gray SL, Larson EB: Risk of dementia and AD with prior exposure to NSAIDs in an elderly community-based cohort. Neurology 2009, 72(22):1899-1905.

11. Esposito E, Di Matteo V, Benigno A, Pierucci M, Crescimanno G, Di Giovanni G: Non-steroidal anti-inflammatory drugs in Parkinson's disease. Exp Neurol 2007, 205(2):295-312

12. McGeer PL, McGeer EG: NSAIDs and Alzheimer disease: epidemiological, animal model and clinical studies. Neurobiol Aging 2007, 28(5):639-647.

13. Jick H, Zornberg GL, Jick SS, Seshadri S, Drachman DA: Statins and the risk of dementia. Lancet 2000, 356(9242):1627-1631.

14. Danesh FR, Anel RL, Zeng L, Lomasney J, Sahai A, Kanwar YS: Immunomodulatory effects of HMG-CoA reductase inhibitors. Arch Immunol Ther Exp (Warsz) 2003, 51:139-148.

15. Peyrin JM, Lasmezas Cl, Haik S, Tagliavini F, Salmona M, Williams A, Richie D, Deslys JP, Dormont D: Microglial cells respond to amyloidogenic PrP peptide by the production of inflammatory cytokines. Neuroreport 1999, 10(4):723-729.

16. Reed-Geaghan EG, Savage JC, Hise AG, Landreth GE: CD14 and Toll-like receptors 2 and 4 are required for fibrillar Ab-stimulated microglial activation. J Neurosci 2009, 29(38):11982-11992.

17. Thellung S, Corsaro A, Villa V, Venezia V, Nizzari M, Bisaglia M, Russo C, Schettini G, Aceto A, Florio T: Amino-terminally truncated prion protein PrP90-231 induces microglial activation in vitro. Ann N Y Acad Sci 2007 1096:258-270.

18. Righi M, Mori L, Libero GD, Sironi M, Biondi A, Mantovani A, Donini SD, Ricciardi-Castagnoli P: Monokine production by microglial cell clones. Eur J Immunol 1989, 19(8):1443-1448.

19. Ranaivo HR, Craft JM, Hu W, Guo L, Wing LK, Van Eldik LJ, Watterson DM: Glia as a therapeutic target: selective suppression of human amyloid- $\beta$ induced upregulation of brain proinflammatory cytokine production attenuates neurodegeneration. J Neurosci 2006, 26(2):662-670.

20. Doens D, Fernandez P: Microglia receptors and their implications in the response to amyloid beta for Alzheimer's disease pathogenesis. J Neuroinflammation 2014, 11(1):48.

21. Khoury JE, Hickman SE, Thomas CA, Cao L, Silverstein SC, Loike JD: Scavenger receptor-mediated adhesion of microglia to [beta]-amyloid fibrils. Nature 1996, 382(6593):716-719.

22. Calingasan NY, Erdely HA, Anthony Altar C: Identification of CD40 ligand in Alzheimer's disease and in animal models of Alzheimer's disease and brain injury. Neurobiol Aging 2002, 23(1):31-39.

23. Becher B, Fedorowicz V, Antel JP: Regulation of CD14 expression on human adult central nervous system-derived microglia. J Neurosci Res 1996, 45(4):375-381.

24. Bate $C$, Boshuizen $R$, Williams A: Microglial cells kill prion-damaged neurons in vitro by a CD14-dependent process. J Neuroimmuno/ 2005, 170(1-2):62-70.

25. Wright SD, Ramos RA, Tobias PS, Ulevitch RJ, Mathison JC: CD14, a receptor for complexes of lipopolysaccharide (LPS) and LPS binding protein. Science 1990, 249(4975):1431-1433.
26. Triantafilou M, Triantafilou K: Lipopolysaccharide recognition: CD14, TLRs and the LPS-activation cluster. Trends Immunol 2002, 23(6):301-304.

27. Reed-Geaghan EG, Reed QW, Cramer PE, Landreth GE: Deletion of CD14 attenuates Alzheimer's disease pathology by influencing the brain's inflammatory milieu. J Neurosci 2010, 30(46):15369-15373.

28. Haziot A, Chen S, Ferrero E, Low MG, Silber R, Goyert SM: The monocyte differentiation antigen, CD14, is anchored to the cell membrane by a phosphatidylinositol linkage. J Immunol 1988, 141(2):547-552.

29. Haziot A, Rong G, Bazil V, Silver J, Goyert S: Recombinant soluble CD14 inhibits LPS-induced tumor necrosis factor-alpha production by cells in whole blood. J Immunol 1994, 152(12):5868-5876.

30. Haziot A, Rong G, Lin X, Silver J, Goyert S: Recombinant soluble CD14 prevents mortality in mice treated with endotoxin (lipopolysaccharide). J Immunol 1995, 154(12):6529-6532

31. Guo Nan Y, Hyejin J, Shinrye L, Ho Won L, Je-Yoel C, Kyoungho S: Role of soluble CD14 in cerebrospinal fluid as a regulator of glial functions. J Neurosci Res 2009, 87(11):2578-2590.

32. Tsumura K: Clinical evaluation of glimepiride (HOE490) in NIDDM including a double blind comparative study versus gliclazide. Diabetes Res Clin Pract 1995, 28(Suppl):S147-S149.

33. Müller G, Dearey EA, Korndorfer A, Bandlow W: Stimulation of a glycosylphosphatidylinositol-specific phospholipase by insulin and the sulfonylurea, glimepiride, in rat adipocytes depends on increased glucose transport. J Cell Biol 1994, 126(5):1267-1276.

34. Müller G, Dearey EA, Punter J: The sulphonylurea drug, glimepiride, stimulates release of glycosylphosphatidylinositol-anchored plasma-membrane proteins from 3 T3 adipocytes. Biochem J 1993, 289(Pt 2):509-521.

35. Bate C, Tayebi M, Diomede L, Salmona M, Williams A: Glimepiride reduces the expression of $\operatorname{PrP}^{C}$, prevents $\operatorname{PrP}^{\mathrm{SC}}$ formation and protects against prion mediated neurotoxicity. PLoS One 2009, 4(12):e8221

36. Moore KJ, Andersson LP, Ingalls RR, Monks BG, Li R, Arnaout MA, Golenbock DT, Freeman MW: Divergent response to LPS and bacteria in CD14-deficient murine macrophages. J Immunol 2000, 165:4272-4280.

37. Stanton JD, Rashid MB, Mensa-Wilmot K: Cysteine-less glycosylphosphatidylinositolspecific phospholipase $C$ is inhibited competitively by a thiol reagent: evidence for glyco-mimicry by p-chloromercuriphenylsulphonate. Biochem J 2002, 366(Pt 1):281-288.

38. Dürig J, Giese A, Schulz-Schaeffer W, Rosenthal C, Schmücker U, Bieschke J Dührsen U, Kretzschmar HA: Differential constitutive and activationdependent expression of prion protein in human peripheral blood leucocytes. Br J Haematol 2000, 108(3):488-495.

39. Duan W, Zhou J, Zhang S, Zhao K, Zhao L, Ogata K, Sakaue T, Mori A, Wei T: ESeroS-GS modulates lipopolysaccharide-induced macrophage activation by impairing the assembly of TLR-4 complexes in lipid rafts. Biochim Biophys Acta 2011, 1813(5):772-783

40. Fernandez-Lizarbe S, Montesinos J, Guerri C: Ethanol induces TLR4/TLR2 association, triggering an inflammatory response in microglial cells. J Neurochem 2013, 126(2):261-273.

41. Becker ML, Visser LE, Trienekens PH, Hofman A, van Schaik RHN, Stricker B: Cytochrome P450 2C9*2 and *3 polymorphisms and the dose and effect of sulfonylurea in type II diabetes mellitus. Clin Pharmacol Ther 2007, 83(2):288-292.

42. Barger SW, Horster D, Furukawa K, Goodman Y, Krieglstein J, Mattson MP: Tumor necrosis factors alpha and beta protect neurons against amyloid beta-peptide toxicity: evidence for involvement of a kappa B-binding factor and attenuation of peroxide and $\mathrm{Ca} 2+$ accumulation. Proc Natl Acad Sci U S A 1995, 92(20):9328-9332.

43. Mattson MP, Barger SW, Furukawa K, Bruce AJ, Wyss-Coray T, Mark RJ, Mucke $\mathrm{L}$ : Cellular signaling roles of TGF beta, TNF alpha and beta APP in brain injury responses and Alzheimer's disease. Brain Res Brain Res Rev 1997 23(1-2):47-61

44. McCoy M, Tansey M: TNF signaling inhibition in the CNS: implications for normal brain function and neurodegenerative disease. $J$ Neuroinflammation 2008, 5(1):45.

45. Tansey MG, McCoy MK, Frank-Cannon TC: Neuroinflammatory mechanisms in Parkinson's disease: potential environmental triggers, pathways, and targets for early therapeutic intervention. Exp Neurol 2007, 208(1):1-25.

46. McAlpine FE, Lee JK, Harms AS, Ruhn KA, Blurton-Jones M, Hong J, Das P, Golde TE, LaFerla FM, Oddo S, Blesch A, Tansey MG: Inhibition of soluble TNF signaling in a mouse model of Alzheimer's disease prevents pre-plaque amyloid-associated neuropathology. Neurobiol Dis 2009, 34(1):163-177. 
47. Terrando N, Monaco C, Ma D, Foxwell BM, Feldmann M, Maze M: Tumor necrosis factor-\{alpha\} triggers a cytokine cascade yielding postoperative cognitive decline. Proc Natl Acad Sci U S A 2010, 107(47):20518-20522.

48. Tobinick E, Gross H: Rapid cognitive improvement in Alzheimer's disease following perispinal etanercept administration. J Neuroinflammation 2008, 5(1):2.

49. Terreni $L$, De Simoni MG: Role of the brain in interleukin-6 modulation. Neuroimmunomodulation 1998, 5(3-4):214-219.

50. D'Arcangelo G, Tancredi V, Onofri F, D'Antuono M, Giovedi S, Benfenati F: Interleukin- 6 inhibits neurotransmitter release and the spread of excitation in the rat cerebral cortex. Eur J Neurosci 2000, 12(4):1241-1252.

51. Tancredi V, D'Antuono M, Cafe C, Giovedi S, Bue MC, D'Arcangelo G, Onofri F, Benfenati F: The inhibitory effects of interleukin- 6 on synaptic plasticity in the rat hippocampus are associated with an inhibition of mitogenactivated protein kinase ERK. J Neurochem 2000, 75(2):634-643.

52. Heine H, Ulmer AJ, El-Samalouti VT, Lentschat A, Hamann L: Decay-accelerating factor (DAF/CD55) is a functional active element of the LPS receptor complex. J Endotoxin Res 2001, 7(3):227-231.

53. Letiembre M, Hao W, Liu Y, Walter S, Mihaljevic I, Rivest S, Hartmann T, Fassbender $\mathrm{K}$ : Innate immune receptor expression in normal brain aging. Neuroscience 2007, 146(1):248-254.

54. Saltiel AR, Sherline P, Fox JA: Insulin-stimulated diacylglycerol production results from the hydrolysis of a novel phosphatidylinositol glycan. J Biol Chem 1987, 262(3):1116-1121.

55. Müller G, Jung C, Wied S, Welte S, Frick W: Insulin-mimetic signaling by the sulfonylurea glimepiride and phosphoinositolglycans involves distinct mechanisms for redistribution of lipid raft components. Biochemistry 2001, 40(48):14603-14620.

56. Haziot A, Ferrero E, Kontgen F, Hijiya N, Yamamoto S, Silver J, Stewart CL, Goyert SM: Resistance to endotoxin shock and reduced dissemination of gram-negative bacteria in CD14-deficient mice. Immunity 1996, 4(4):407-414

57. Pike LJ: Lipid rafts: heterogeneity on the high seas. Biochem J 2004, 378(Pt 2):281-292.

58. Mayor S, Rao M: Rafts: scale-dependent, active lipid organization at the cell surface. Traffic 2004, 5(4):231-240.

59. Lingwood D, Ries J, Schwille P, Simons K: Plasma membranes are poised for activation of raft phase coalescence at physiological temperature. Proc Natl Acad Sci U S A 2008, 105(29):10005-10010.

60. Lingwood D, Simons K: Lipid rafts as a membrane-organizing principle. Science 2010, 327(5961):46-50.

61. Hancock JF: Lipid rafts: contentious only from simplistic standpoints. Nat Rev Mol Cell Biol 2006, 7(6):456-462.

62. Helms JB, Zurzolo C: Lipids as targeting signals: lipid rafts and intracellular trafficking. Traffic 2004, 5(4):247-254.

63. Triantafilou M, Miyake K, Golenbock DT, Triantafilou K: Mediators of innate immune recognition of bacteria concentrate in lipid rafts and facilitate lipopolysaccharide-induced cell activation. J Cell Sci 2002, 115(12):2603-2611.

64. Walter S, Letiembre M, Liu Y, Heine H, Penke B, Hao W, Bode B, Manietta N, Walter J, Schulz-Schuffer W, Fassbender K: Role of the toll-like receptor 4 in neuroinflammation in Alzheimer's disease. Cell Physiol Biochem 2007, 20(6):947-956.

65. Song M, Jin J, Lim JE, Kou J, Pattanayak A, Rehman JA, Kim HD, Tahara K, Lalonde R, Fukuchi K: TLR4 mutation reduces microglial activation, increases Abeta deposits and exacerbates cognitive deficits in a mouse model of Alzheimer's disease. J Neuroinflammation 2011, 8:92.

66. Jin JJ, Kim HD, Maxwell JA, Li L, Fukuchi K: Toll-like receptor 4-dependent upregulation of cytokines in a transgenic mouse model of Alzheimer's disease. J Neuroinflammation 2008, 5:23.

67. Eisenberg S, Shvartsman DE, Ehrlich M, Henis Yl: Clustering of raft-associated proteins in the external membrane leaflet modulates internal leaflet H-Ras diffusion and signaling. Mol Cell Biol 2006, 26(19):7190-7200.
68. Gri G, Molon B, Manes S, Pozzan T, Viola A: The inner side of T cell lipid rafts. Immunol Lett 2004, 94(3):247-252

69. Field KA, Holowka D, Baird B: Fc epsilon Rl-mediated recruitment of p53/ 56lyn to detergent-resistant membrane domains accompanies cellular signaling. Proc Natl Acad Sci U S A 1995, 92(20):9201-9205.

70. Hunter T: Signaling - 2000 and beyond. Cell 2000, 100(1):113-127.

doi:10.1186/1742-2094-11-115

Cite this article as: Ingham et al:: Glimepiride reduces CD14 expression and cytokine secretion from macrophages. Journal of Neuroinflammation 2014 11:115.

\section{Submit your next manuscript to BioMed Central and take full advantage of:}

- Convenient online submission

- Thorough peer review

- No space constraints or color figure charges

- Immediate publication on acceptance

- Inclusion in PubMed, CAS, Scopus and Google Scholar

- Research which is freely available for redistribution 